\title{
Chapter 8 \\ Sources and Drivers of Agricultural Growth in Bihar
}

\author{
Anwarul Hoda, Ashok Gulati, Shyma Jose, and Pallavi Rajkhowa
}

\subsection{Introduction}

Agriculture dominates Bihar's economy, providing employment to $53.6 \%$ of the total workforce, higher than the national average of 46.9\% (Labour Bureau 2015-16). A high proportion of the population $(88.5 \%)$ lives in rural areas. The share of agriculture and allied activities in gross state domestic product has declined from $34.9 \%$ in the triennium ending (TE) 2003-04 to 20.0\% in TE 2017-18 (at constant prices 201112). The gross state domestic product (GSDP) of Bihar grew at $3.1 \%$ for the period from 2001-02 to 2017-18. The growth even at this modest rate has reduced poverty, which declined from $54.4 \%$ in $2004-05$ to $33.7 \%$ in $2011-12$. However, the state still has a high prevalence of poverty. In 2015-16, the average income of a farming household in the state was Rs. 7175 per month against the national average of Rs. 8931 per month, indicating the dismal agricultural scenario in the state (NABARD 2018). Small and marginal farmers account for $96.9 \%$ of the landholdings and $75.9 \%$ of Bihar's cultivated area (Agriculture Census 2015-16).

Bihar has three agro-climatic zones, north-west, north-east and south, and all three are suitable for agricultural diversification. The state is endowed with abundant natural resources, fertile soil and groundwater. The distinct agro-climatic zones give the state a congenial environment for the cultivation of a variety of commercial crops, vegetables and fruits. The state has also started growing flowers on a large scale for both the domestic and export markets. The state was awarded the Krishi

\footnotetext{
A. Hoda $\cdot$ S. Jose

Indian Council for Research on International Economic Relations, New Delhi, India
A. Gulati (凷
Indian Council for Research on International Economic Relations, New Delhi, India
e-mail: agulati115@gmail.com
P. Rajkhowa
Centre for Development Research (ZEF), University of Bonn, Bonn, Germany


Karman Award for rice production in the year 2013 and for maize production in 2016. However, constraints like the high density of rural population and year-to-year variation in rainfall have increased the volatility in agricultural growth and proved to be an obstacle to agricultural diversification. Against this background, this study examines the sources and drivers of agricultural growth and recommends policy initiatives to enhance agricultural growth as well as farm income.

In this chapter, we focus on the performance of the agricultural sector in the state of Bihar by identifying the sources of growth as well as the role of existing policies. Section 8.2 discusses the overview of agriculture in the state of Bihar. Section 8.3 discusses the composition and the sources of growth of agriculture. Section 8.4 presents the drivers of agricultural growth. Section 8.5 presents an assessment of the budgetary allocations to agricultural and allied activities. Section 8.6 draws the conclusion and policy recommendations.

\subsection{Overview and Composition of the Agriculture Sector}

Bihar has a geographical area of 93.60 lakh ha, which is divided by the river Ganges into two parts, north Bihar and south Bihar. The gross sown area in Bihar was around 75.72 lakh ha and the gross irrigated area was around 52.68 lakh ha in 2015-16. The cropping intensity in the state has increased from 1.37 in 2009-10 to 1.45 in 2014-15. Bihar has around 122.2 million (2019) people, accounting for about $8.8 \%$ of India's population. Based on the soil characteristics, rainfall, temperature and terrain, the state has been divided into three distinct agro-climatic zones: north-west (agro-climatic zone I), north-east (agro-climatic zone II) and south (agro-climatic zone III) (see Fig. 8.1). In the north-west zone (13 districts), the soil type is mostly sandy loam; in the north-east zone (8 districts), it is loam or clay loam and in the South Zone (17 districts) it is mostly sandy loam, loam, clay or clay loam.

There are wide climatic variations in the three zones in Bihar. The north-east zone receives the highest rainfall ranging between 1200 and $1700 \mathrm{~mm}$, the southern part the least, ranging between 900 and $1300 \mathrm{~mm}$ and the north-west an average of 1040-1450 mm. Although the annual rainfall appears sufficient on the average for agricultural operations, the year-to-year variations result in both floods and droughts in different years (Fig. 8.2a, b). The state experienced floods in 2001, 2002, 2003, 2004, 2007, 2008, 2013, 2016 and 2017, but it was declared drought-affected in the years 2005, 2007, 2009, 2010 and 2012, with more than 20\% deficiency in rainfall. According to the Water Resource Department, around $76 \%$ of the population in northern Bihar is subject to floods whereas southern Bihar is prone to severe drought. 


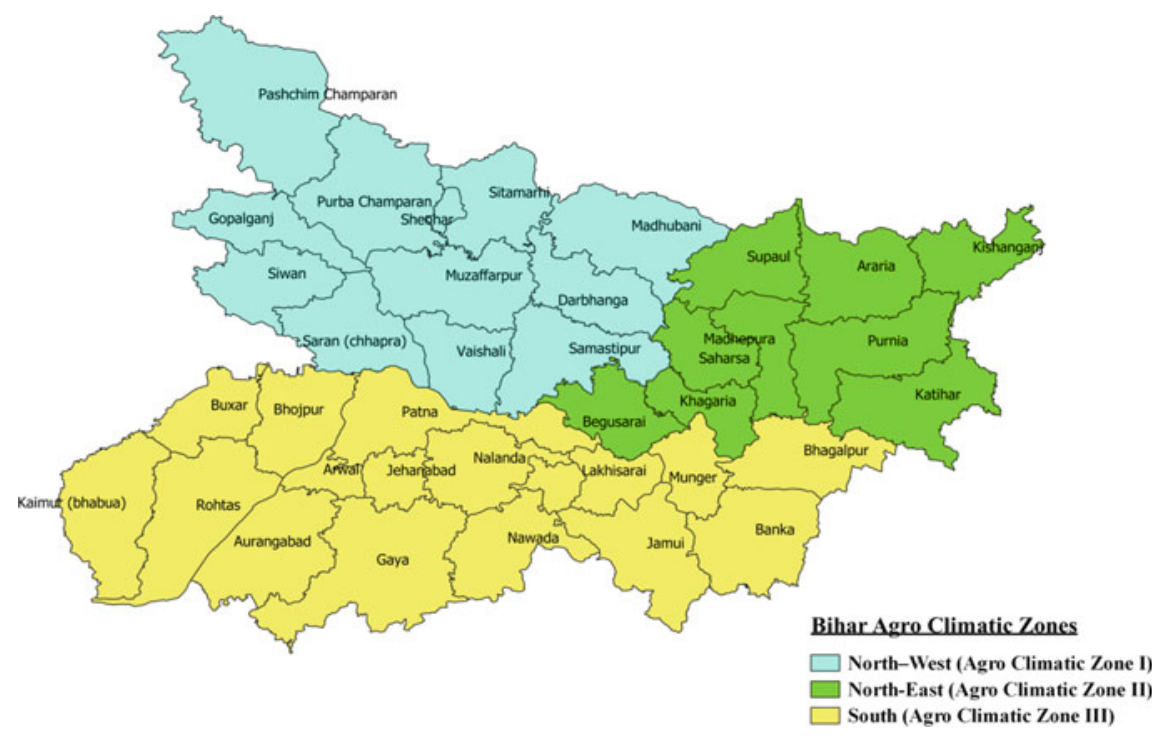

Fig. 8.1 Agro-climatic zones in Bihar. Source Created using QGIS from Government of Bihar's Data

\subsubsection{Agricultural Growth Trend in Bihar}

The agricultural growth rate in Bihar was 3.1\%, slightly lower than the all-India agricultural growth rate of $3.4 \%$ during the period from 2001-02 to 2017-18 (at constant 2011-12 prices). Agricultural growth in Bihar has been very volatile in these years as can been seen in Fig. 8.3. The volatility is the result of recurring floods alternating with droughts. The years in which contraction has occurred are those in which the state experienced either floods or droughts.

\subsubsection{Land Utilisation in Bihar}

The agricultural sector in the state is dominated by small and marginal farmers. According to the Agricultural Census (2015-16), marginal farmers (those with landholding size of less than 1 ha) accounted for $91.21 \%$ of the holdings and $57.73 \%$ of the area. Small farmers (with 1-2 ha) constituted $5.75 \%$ of the holding and cultivated $18.25 \%$ of the area. As Table 8.1 shows, the trend towards fragmentation seems to have slowed down in the last five years.

The high density of rural population is the major factor leading to fragmentation of holdings in the state. Arable land is scarce in Bihar with the gross cropped area per 100 persons only at 7.4 ha as compared to 32.6 ha in Madhya Pradesh, 28.3 ha in Punjab and 20.9 ha in Gujarat in TE 2014-15 (see Fig. 8.4). 


\section{a. Drought-prone regions}

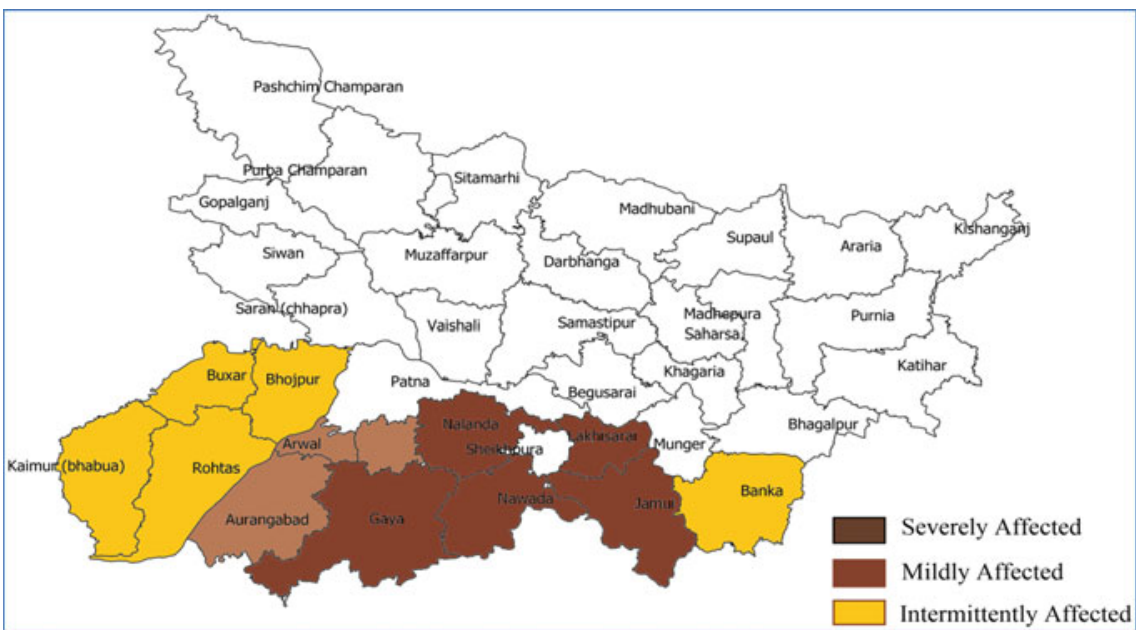

\section{b. Flood-prone regions}

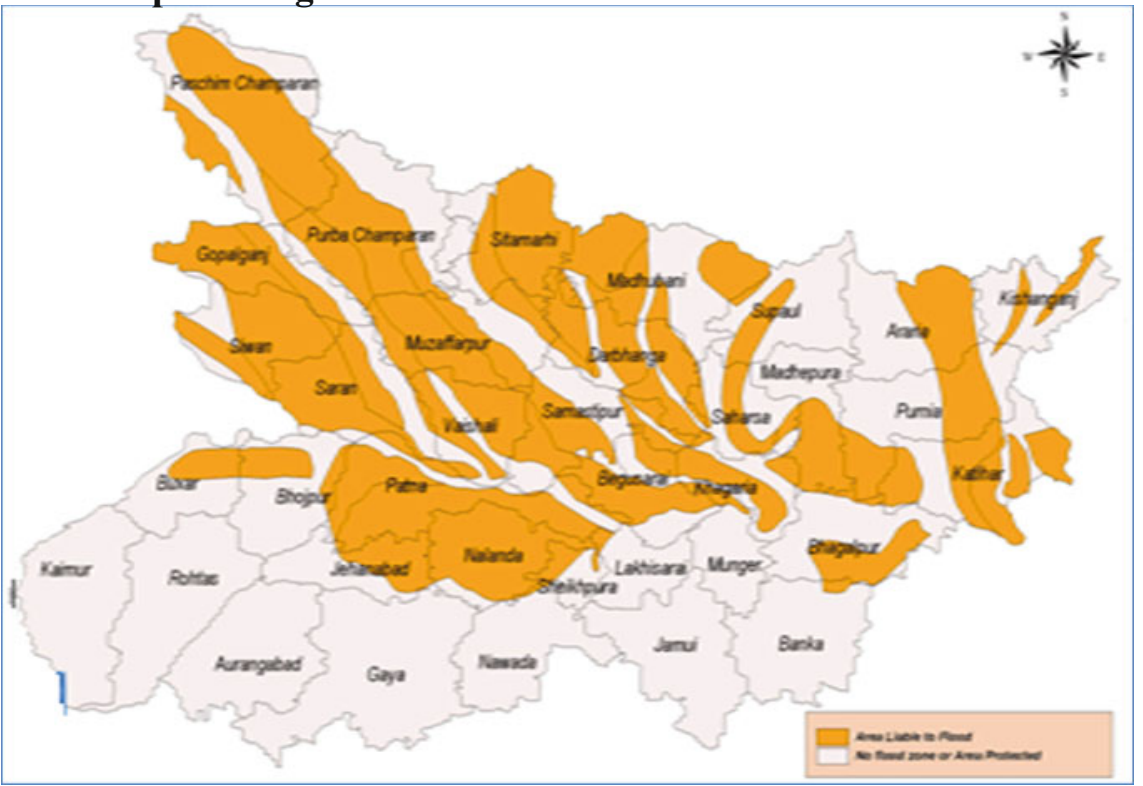

Fig. 8.2 Drought and Flood prone regions in Bihar. a Drought-prone regions. Source Created using QGIS from NIDM and UNDP. b Flood-prone regions. Source NIDM and UNDP 


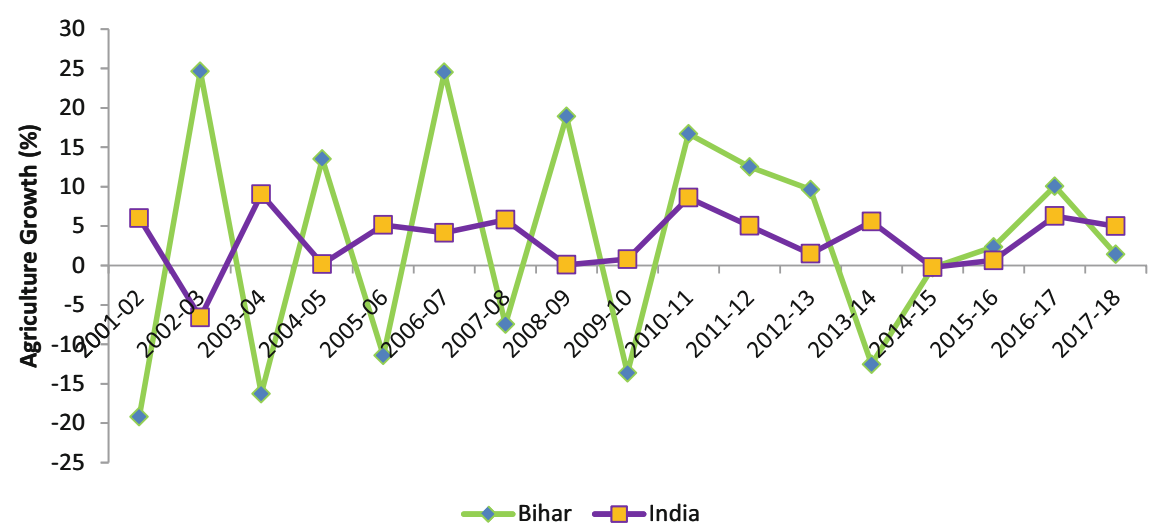

Fig. 8.3 Agricultural growth in Bihar (2001-02 to 2017-18). Source Government of India, Central Statistical Organisation

\subsubsection{Cropping Pattern in Bihar}

Cereals dominate the state's agriculture. In TE 2015-16, the cereal production accounted for as much as $79.8 \%$ of the gross cropped area as compared to national average $50.8 \%$. Rice is the dominant kharif crop and wheat, the most important rabi crop. Maize has been rising in importance, with acreage under it increasing. From Fig. 8.5, it can be seen that the share of acreage under rice has declined while that under wheat and maize has increased. Both the decline in the acreage under rice and the increase in acreage under wheat and maize are more pronounced in the state than at the national level. Other features of the changing cropping pattern in Bihar are an expansion of acreage under maize, a decline in the acreage under pulses and an increase in the acreage under sugarcane.

\subsubsection{Determinants of Agriculture Growth}

Apart from good infrastructure, agriculture needs timely supply of adequate quantities and quality of agricultural inputs, crop insurance, price incentives, agricultural marketing and storage facilities to promote agricultural productivity and growth.

\section{Agricultural Inputs in Crop Production}

\section{Seeds}

During the past ten years, Bihar has implemented an ambitious seed programme comprising a subsidy for the production and purchase of certified seeds, a revival of previously dormant Bihar Rajya Beej Nigam (BRBM), strengthening of Bihar's seed certification agency and multiplication of foundation and breeder seeds by state 
A. Hoda et al.

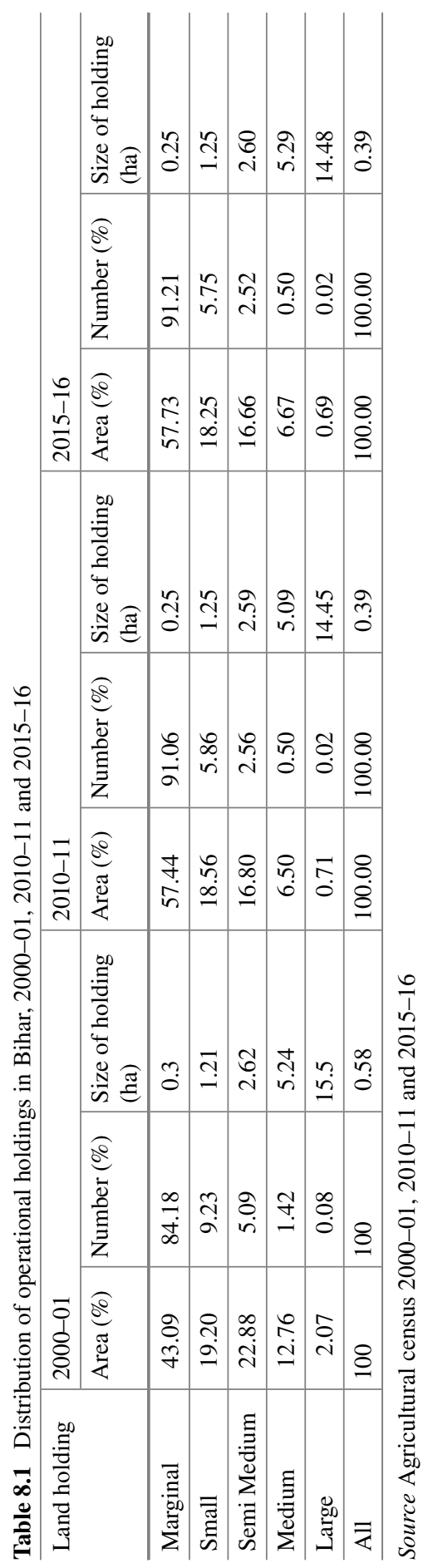




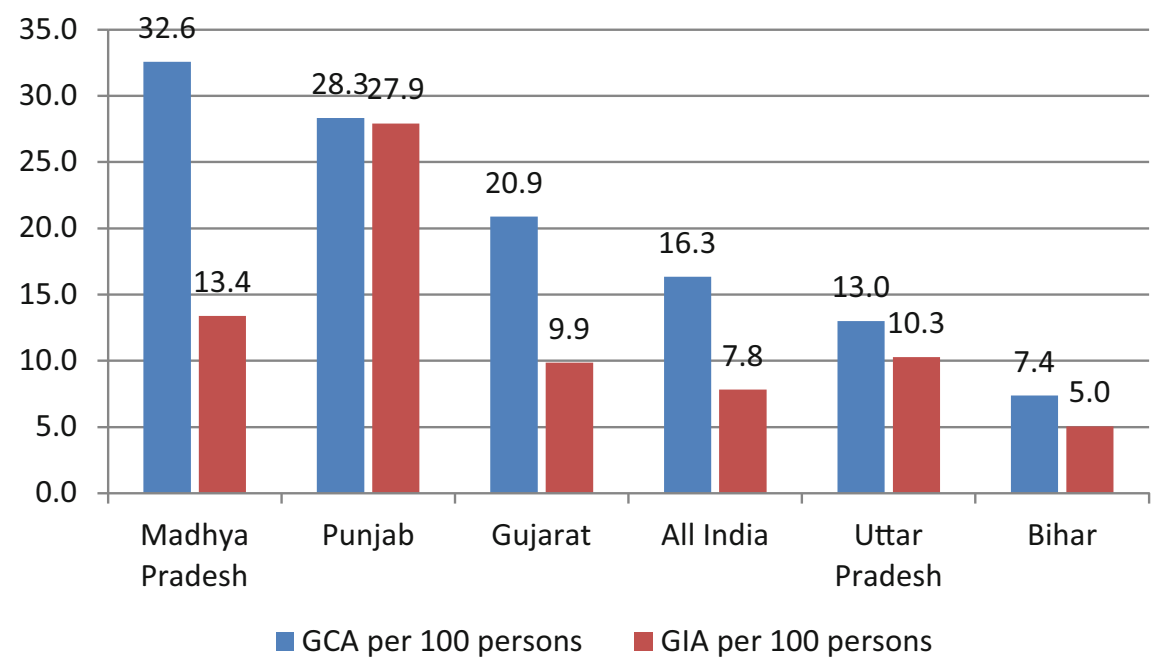

Fig. 8.4 GCA and GIA per 100 persons (in ha) TE 2014-15. Source Directorate of Economic and Statistics, GoI

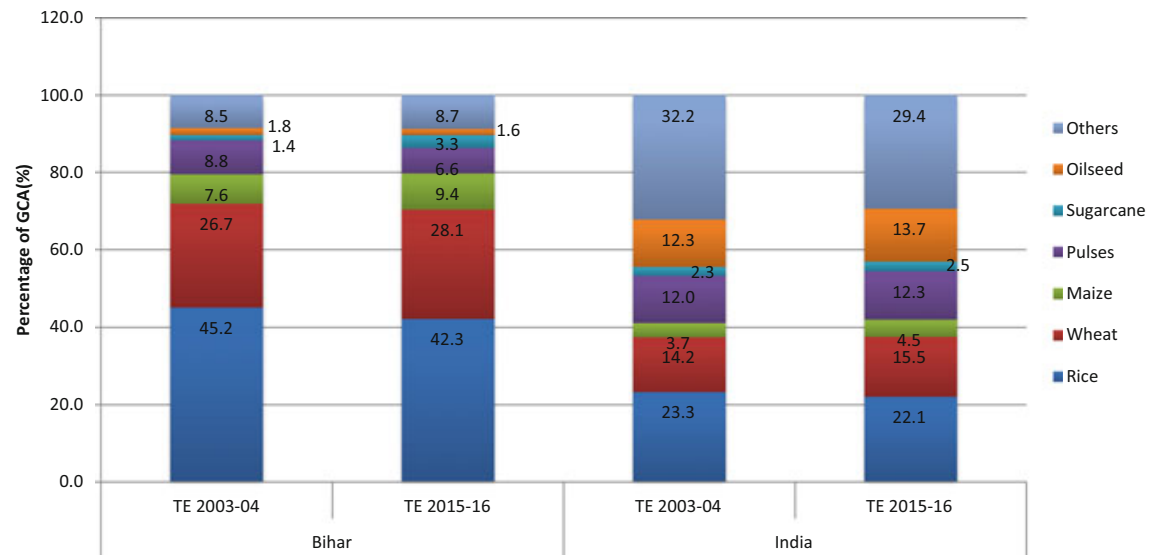

Fig. 8.5 Area under major crops in Bihar (percentage of gross cropped area). Source Directorate of Economic and Statistics, GoI

farms. In the early 2000s, the productivity of major crops was depressed by low seed replacement rates (SRR) in major crops like paddy and wheat. Due to a sustained effort by the state government, the SRR has registered considerable improvement over the last 15 years or so. The SRR for paddy has increased from $10.0 \%$ in 2004 05 to $42.8 \%$ in $2016-17$ and for wheat, from 9.0 to $20.3 \%$ over the same period (Fig. 8.6). The most impressive improvement has been in the case of winter maize, 


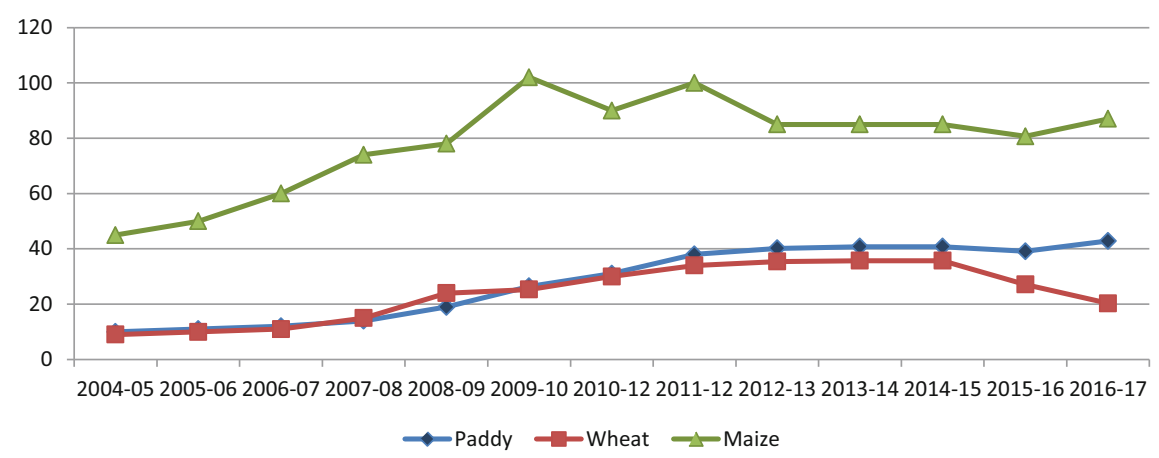

Fig. 8.6 Seed Replacement Rate Wheat, Paddy and Maize in Bihar (\%). Source Department of agriculture, GOB. Note Data for maize includes only rabi maize

where the SRR has risen from 45.0 to $87.0 \%$ over this period. In fact, Bihar's SRR for maize is now far higher than the all-India average of $64.7 \%$.

\section{Fertiliser}

Data available from the state government show that the consumption of fertilisers per hectare in the state has been consistently above the national average during the last ten years (Fig. 8.7). In 2015-16, the consumption in Bihar was around $201 \mathrm{~kg} / \mathrm{ha}$ while the national average was $130.7 \mathrm{~kg} / \mathrm{ha}$. However, the data provided by the Directorate of Economics and Statistics (DES) shows that wheat cultivation in

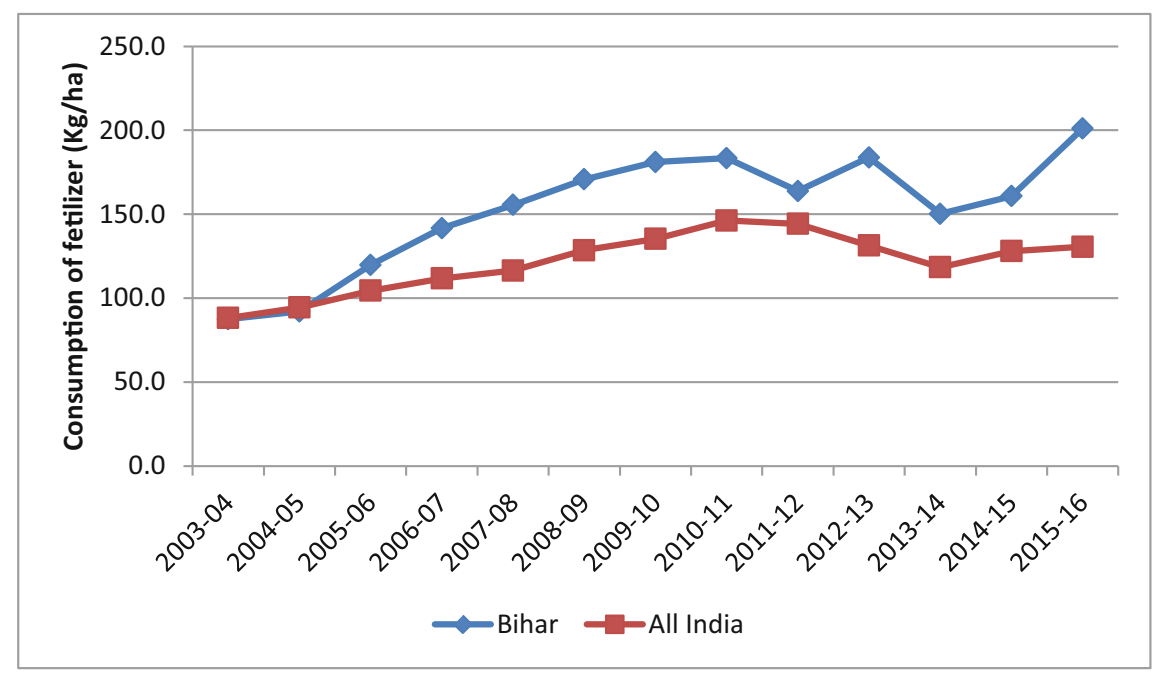

Fig. 8.7 Consumption of fertilisers in Bihar. Source Department of Agriculture Bihar, several issues of the Economic Survey of Bihar and Agriculture Statistics at a Glance, several issues 
Bihar required $125 \mathrm{~kg} / \mathrm{ha}$ while paddy required $97 \mathrm{~kg} / \mathrm{ha}$ in $2012-13$. This discrepancy in fertiliser consumption data provided by DES raises the question of whether subsidised fertilisers are being diverted to neighbouring countries (Gulati 2016).

The discussion above highlights how low productivity in Bihar is not due to low utilisation of productivity augmenting inputs. In fact, the state's farmers have been investing heavily in assets such as quality seeds, fertilisers and farm machines. This increasing investment in agricultural inputs has taken place even though the state lags behind the national average in the disbursement of agricultural credit from institutional sources. What is impeding the disbursement of institutional credit is the slow pace of implementation of the Kisan Credit Card (KCC), which leaves a large number of farmers dependent on high-cost, non-institutional lending sources. The total number of KCCs issued by banks in Bihar (scheduled commercial banks, regional rural banks and central co-operative banks) has been declining over the last few years. The achievement percentage against total targets for all banks was $71.6 \%$ in $2013-14$, which declined to $35.5 \%$ in $2017-18$. The absence of updated records of applicants could be a reason for the lower achievement against a reduced target in 2017-18.

As land records have not been updated, and the land ownership act as collateral security to avail of institutional credit, the scheduled commercial banks, regional rural banks and central co-operative banks recorded slow growth of agricultural credit. However, the state is seized of the problem and is taking action to update its records. As soon as progress is made on this front, it will be possible for farmers to access more agriculture credit for purposes such as mechanisation and the expansion of crop and livestock production.

\section{Crop Insurance}

The world over, governments are increasingly relying on crop insurance to support agriculture. In India, the Pradhan Mantri Fasal Bima Yojana (PMFBY) was implemented in 2016. Dissatisfied with its experience after the PMFBY was implemented, Bihar introduced its own crop insurance scheme-Bihar State Crop Assistance Scheme (Bihar Rajya Fasal Sahayata Yojana). In the Pradhan Mantri Fasal Bima Yojana, the centre and state each had to pay $49 \%$ of the premium amount while the farmer had to pay only $2 \%$ of the premium amount. Under the state's crop assistance scheme, the registered farmer will not be charged any premium but can avail of the benefits when they suffer crop damage due to natural calamities. Under this scheme, the state government will provide Rs. 7500 per ha as assistance for up to two hectares to registered farmers if their crop is less than $20 \%$ of a threshold production limit (Vajpayee 2018). This scheme will increase the fiscal burden on the state government as a large proportion of the financial resources devoted to the agricultural sector may have to be transferred to this scheme. 


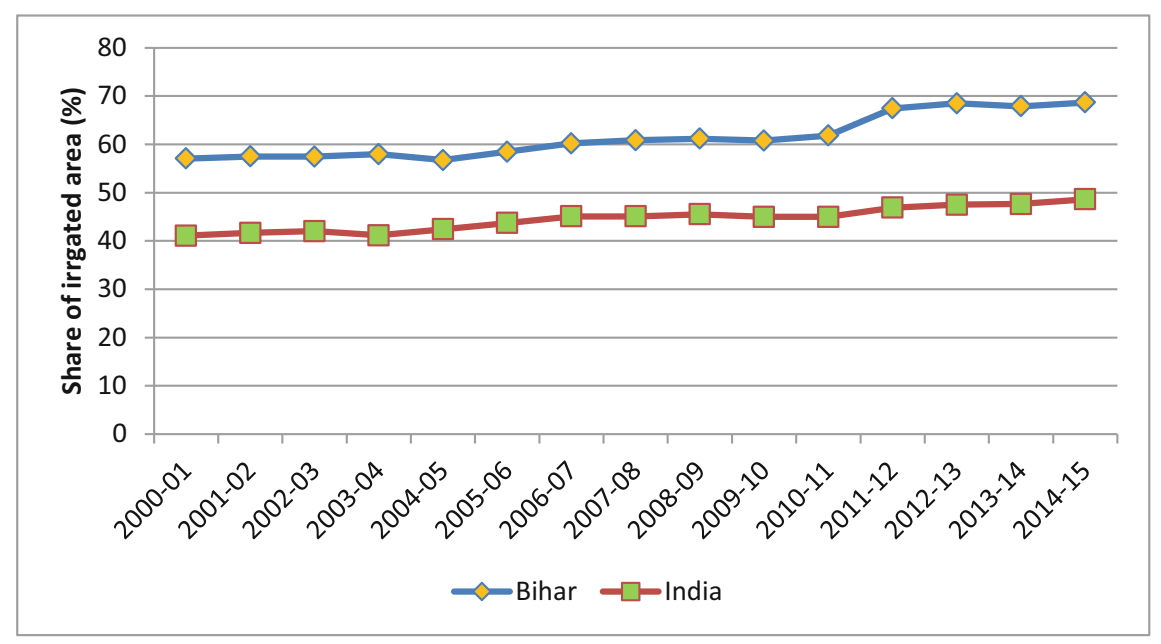

Fig. 8.8 Gross irrigated area as a percentage of gross cropped area. Source Directorate of Economics \& Statistics, GoI

\section{Infrastructure for Agriculture}

\section{Irrigation}

We have alluded earlier to the fact that while normal rainfall received by Bihar is sufficient to sustain agriculture, there are spatial and temporal uncertainties surrounding rainfall. As a result, farming in Bihar remains substantially dependent on irrigation. The irrigation ratio (the gross irrigated area as a proportion of the gross cropped area) in Bihar was more favourable $(68.7 \%)$ as compared to the country as a whole (48.6\%) during the period 2001-02 to 2014-15 (Fig. 8.8).

The source wise picture of the evolution of irrigation during the period under consideration in the state is given in Fig. 8.9. Tube wells and canals are the main sources of irrigation in Bihar, contributing around 65.3 and $28.9 \%$ of the GIA respectively and there was modest expansion in the number of tube wells and canals during the period between TE 2003-04 and TE 2016-17. However, irrigation from tanks has been shrinking in Bihar as can be seen in Fig. 8.9.

Bihar's ultimate irrigation potential (UIP) stands at 117.54 lakh ha, of which 53.53 lakh ha can be irrigated through major and medium projects and 64.01 lakh ha through minor irrigation (including both flow and lift irrigation) (Fig. 8.10). If this potential is exploited fully, Bihar can more than cover its total cultivable area (62.9 lakh ha in TE 2014-15). As per Central Water Commission (CWC), Bihar had achieved $53.7 \%$ of its total irrigation potential from major and medium projects and $59.4 \%$ from minor irrigation projects by 2006-07. If we compare these figures to the latest figures given by the Economic Survey of Bihar 2017-18, it appears that the irrigation potential created through major and medium projects up to March 2017 has improved to $55.4 \%$, and through minor irrigation projects to $63.7 \%$. There is 


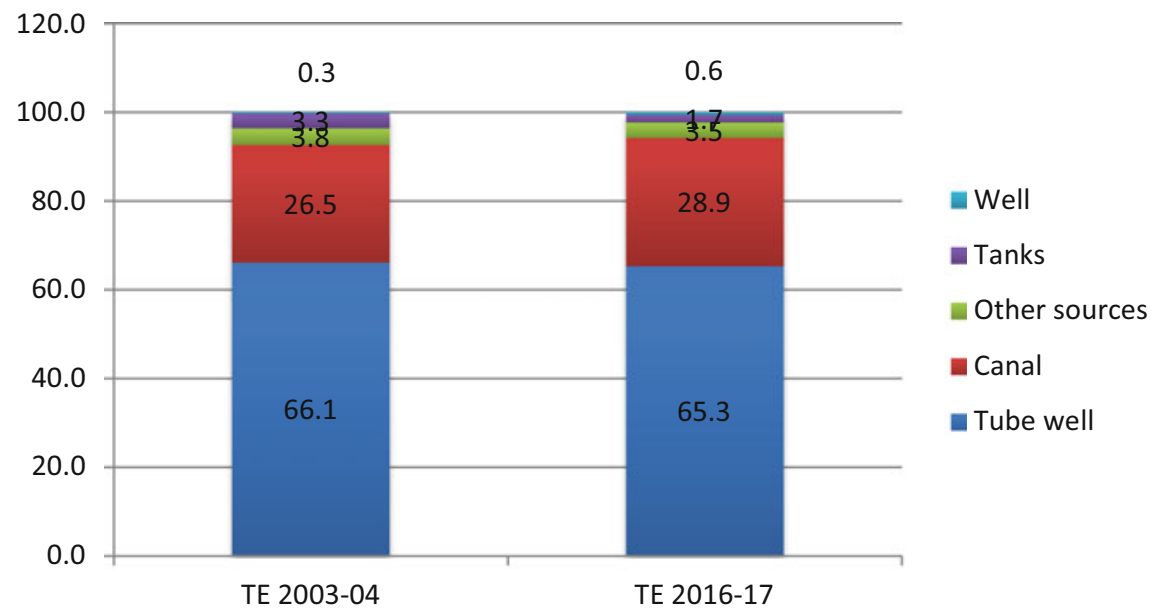

Fig. 8.9 Source-wise Irrigation (per cent of gross irrigated area). Source Directorate of Economics and Statistics, GoI

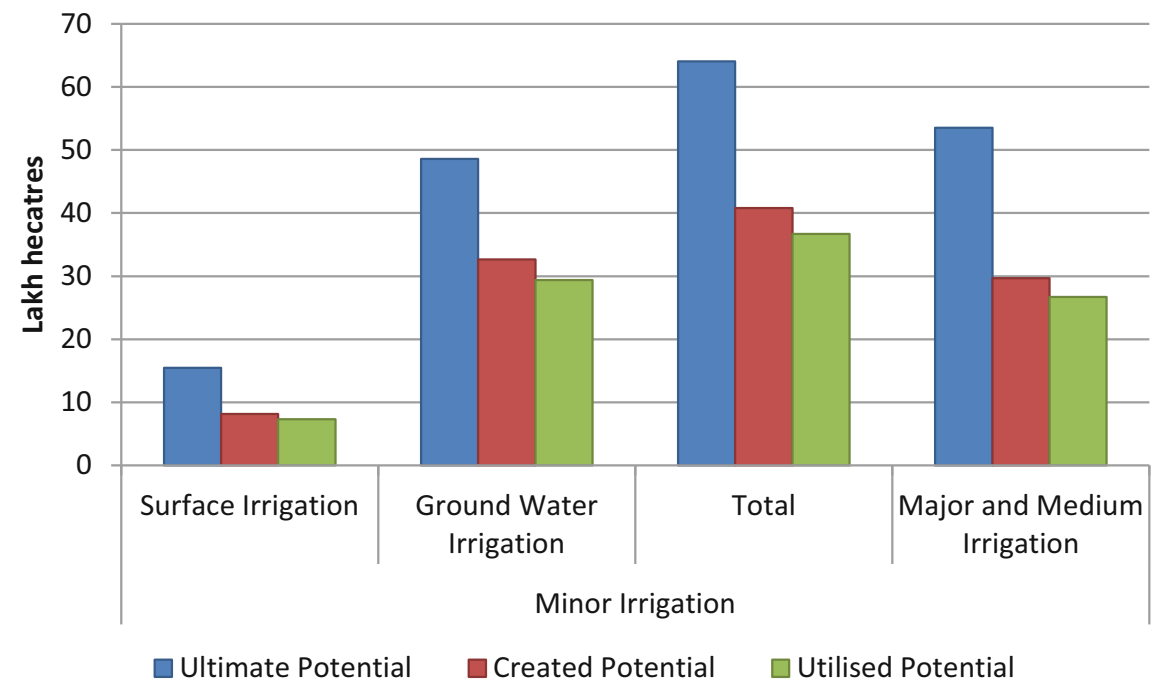

Fig. 8.10 Status of water resources in Bihar (in lakh ha). Source Department of Minor Water Resources, GOB. Note Potential in lakh ha; created and utilised potential is up to March 2017

still substantial scope to expand surface water irrigation in the state through a major, medium as well as minor flow projects. There is also scope for restoring the irrigation potential, which has been lost due to heavy sedimentation and breaches in irrigation canals (Economic Survey 2014-15). Further, the irrigation potential lost due to the 
fall in the water table because of prolonged spells of deficient rains needs to be restored by rejuvenating aquifers through watershed projects.

\section{Flood protection}

We have already been seen how critically agriculture has been affected by variation in water availability. Construction of embankments has been the main strategy adopted by the state government to contain damage from floods. Up to 2017, a cumulative length of $3789.96 \mathrm{~km}$ of embankments had been constructed, protecting an area of 3.6 million ha from floods, which constitutes $52.8 \%$ of the flood-affected areas. The Economic Survey 2017-18 mentions that there is a plan for the protection of a further 3.43 lakh ha from flood by the construction of new embankments. There are indications, however, that the state government may be moving away from reliance only on building embankments. The new strategy for flood management adopted by the state government puts more emphasis on rehabilitating pre-existing natural drainage systems to give enough room to rivers to flow.

The limitations of building embankments are well-known. The areas outside the embankments are denied the benefit of the rich alluvial sediments that the river flows bring. Besides, the silt brought by the rivers raises riverbeds. Rainwater gets stuck outside the embankments and river water seeps through the embankments into the countryside. Additionally, embankments restrict the flow of waters from tributaries to the main river. Although sluice gates facilitate the process of directing water from tributaries to the main river during the offseason, during the peak flood season, the sluice gates cannot be opened because of the risk of the main river flowing back into the tributaries.

Further, there is also the risk of breach of embankments, which can create havoc for populations residing close to embankments (Mishra 1999). For these reasons, experts and planners have been looking beyond embankments for a permanent solution to the problem of flooding. In the past, the thinking has been that there is substantial potential for upstream reservoir storage in the Himalayan headwaters, which could be harnessed through large multipurpose dams to provide three benefits, viz., regulate river flows to contain floods, deliver irrigation water and produce hydropower. A recent evaluation of the Ganges Strategic Basin Assessment (SBA) undertaken by the World Bank (Sadoff et al. 2012) in co-operation with several leading research institutions has come to some sobering conclusions. The potential to control floods by providing for upstream storage is limited. There could be benefits from irrigation in the dry season but in Bihar, where the water table is high even in the dry season, such irrigation could cause harm by increasing waterlogging. The SBA confirms the existence of considerable hydropower potential — as much as 40,000 megawatts of economically feasible hydropower potential is believed to exist. But the development of power would be capital intensive and would take several years to implement. The SBA report does not touch upon the environmental aspects, which, according to some authors, make the proposal for the construction of multipurpose dams in the Himalayas a nonstarter because "in the Himalayas, we confront one of the most fragile ecosystems in the world" (Shah 2016). 


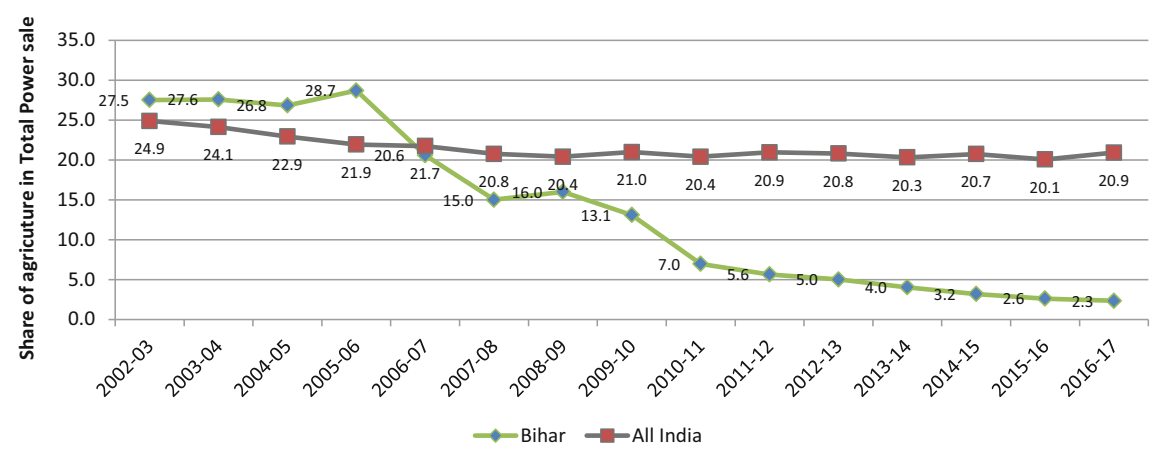

Fig. 8.11 Agriculture share in total power sales. Source Central Electricity Authority, various years

\section{Power for Agriculture}

An important determinant of development is the availability of adequate, reliable and quality power at a competitive rate but the state is chronically deficient in this regard. In 2013-14, the state generated only 94 MW from its own sources and imported around $2241 \mathrm{MW}$ from other sources. Per capita power consumption in the state is only $256.3 \mathrm{kWh}$, much lower than the all-India average of $978.1 \mathrm{kWh}$. Bihar is almost entirely dependent on central sector allocations to meet its energy demand. The availability of ample power supplies from the central grid in recent months has reduced the pressure to increase domestic generation and enabled the government to focus on improving transmission and distribution. However, Bihar has recently made good progress in the renovation of existing units and the construction of new ones and it is expected that, in about a year or two, it will be able to meet from its own generation close to $50 \%$ of the power needs of about $3500 \mathrm{MW}$.

The share of agriculture in total power sales was higher in the state than the allIndia average from 2002-03 to 2005-06. But it has fallen sharply since then as can been seen in Fig. 8.11.

The data on power intensity, i.e. the ratio of electricity used per hectare, underscores the extremely low use of electricity by the agricultural sector in Bihar (Fig. 8.12). Total power sales to agriculture per hectare of gross cropped area for TE 2014-15 were $42.7 \mathrm{kWh} / \mathrm{ha}$ for Bihar against the all-India level of $790.3 \mathrm{kWh} / \mathrm{ha}$.

The relative position of Bihar as compared to the national average in the rural electrification infrastructure and rural power supply is also mirrored in the progress made over the last decade or so in the energisation of pump sets, whether for tube wells or wells. The number of energised pump sets in Bihar was 34.8 per 1000 ha of gross cropped area in 2000-01; it had only marginally increased to 38.7 per 1000 ha in 2017-18. At the all-India level, the number of energised pump sets increased from 68.2 per 1000 ha in 2000-01 to 108.0 per 1000 ha in 2017-18.

The progressive decline in the quantity and quality of power supplied by power utilities has increased the dependence of farmers in Bihar on diesel tube wells. Further, the increase in diesel prices have increased the cost of irrigation and reduced 


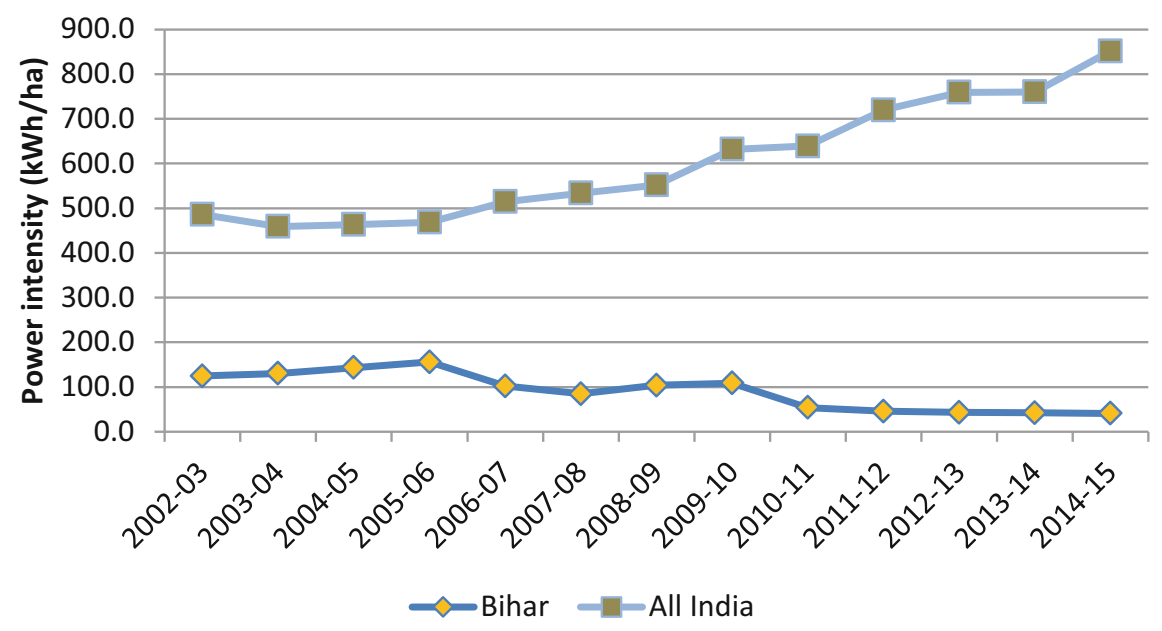

Fig. 8.12 Power intensity (power sales/GCA (KWh/ha), 2002-03 to 2014-15. Source Central Electricity Authority and DES, various years

the profitability of farming in Bihar. The poor state of power supplies for irrigation is one of the main reasons for the plentiful supplies of groundwater in the state's aquifers not being fully exploited. Against the ultimate lift irrigation potential of 4.9 million ha, an irrigation potential of only 3.1 million ha has been created. In order to expand coverage and bring down the cost of cultivation, the government has to provide assured supply of power for agriculture by increasing the expenditure on transmission and distribution to rural areas. The low and dwindling use of power in agriculture can be attributed to the weak distribution and transmission infrastructure, which results in interruptions as well as poor quality of supply.

However, with the recent initiatives of the central and state governments, the situation is expected to change dramatically in the next two years. Under the Deen Dayal Upadhaya Gram Jyoti Yojana, the Government of India has sanctioned 38 projects valued at Rs. 5856.35 crore. Seventy per cent of the allocation of Rs. 4439.69 crore has been earmarked for feeder segregation of power supplies for irrigation and the remaining for system strengthening. The entire work on feeder segregation has been bid out and implementation has already begun. In addition, the state government has taken a loan of Rs. 800 crore from the Asian Development Bank (ADB) to undertake the work of strengthening the transmission system. The latest data on the implementation of DDUGJY in Bihar shows impressive progress in strengthening of the distribution and transmission infrastructure in the state. Up to August 31, 2019, the state had received an advance of Rs. 6500.71 crore of which Rs. 4630.23 crore was for feeder separation and the physical achievement was already $75 \%$.

After the launch of the solar pumping programme for irrigation and drinking water by the Ministry of New and Renewable Energy (MNRE), the state has made a good start in solar pumping. Bihar supplemented the Government of India subsidy of $30 \%$ with a $45 \%$ subsidy of its own. According to the Economic Survey of Bihar 


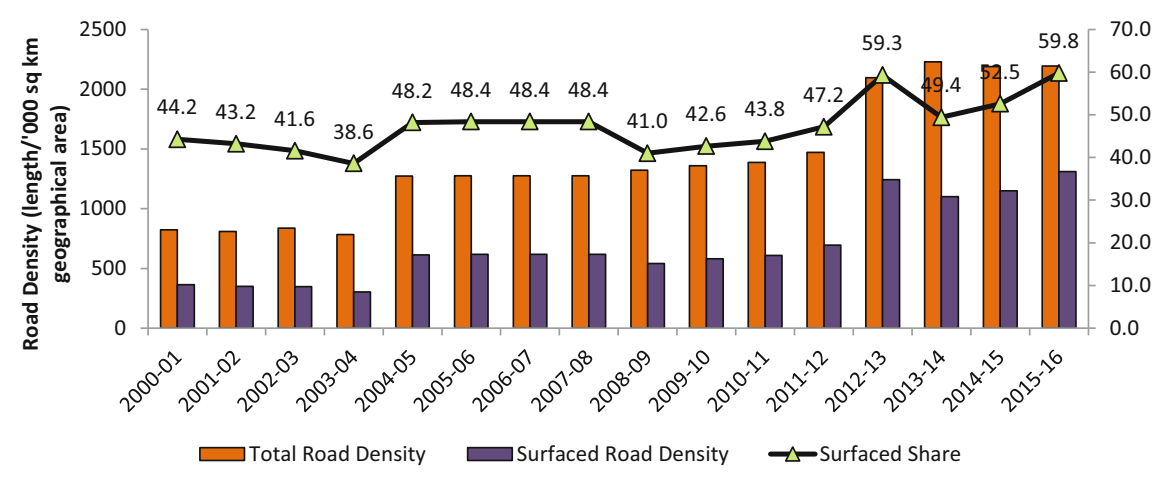

Fig. 8.13 Total and surfaced road density in Bihar. Source Basic Road Statistics, Ministry of Road, Transport and Highways

(2018-19), the state government has installed 995 solar water pumping sets under the Mukhyamantri Naveen and Naveenkarniya irrigation scheme and 521 solar water pumping sets under the Bihar Saur Kranti irrigation scheme up to October 2016. It, however, has not been possible to make arrangements to enable farmers to sell surplus power back to the grid.

\section{Roads}

The roadways infrastructure is critical for agricultural growth as roads facilitate trade, connect input and output markets, promote the development of backward regions and improve farm income. The investment in roads and bridges has tripled in the state during the last decade, the total public expenditure increasing from Rs. 2.6 thousand crores in 2007-08 to Rs. 7.5 thousand crores in 2017-18, which was around 4.7\% of the total budget in that year. The state government invested $14.7 \%$ of public investment on road and bridges, which amounted to 1.5\% of GSDP in 2017-18.

Figure 8.13 shows the progress in the state in total road density, surfaced road density and share of surfaced roads to total roads during the period from 2000-01 to 2015-16. In the latest year for which data are available (2015-16), the total road density in Bihar $\left(2193 \mathrm{~km}\right.$ per $\left.1000 \mathrm{~km}^{2}\right)$ and surfaced road density $(1311 \mathrm{~km}$ per $\left.1000 \mathrm{~km}^{2}\right)$ is slightly higher than the all-India average $\left(1430 \mathrm{~km}\right.$ per $1000 \mathrm{~km}^{2}$ and $1009.5 \mathrm{~km}$ per $1000 \mathrm{~km}^{2}$ respectively) but what is more crucial is that the surfaced road share in total roads $(59.8 \%)$ is much lower than the national average (70.6\%).

\section{Agricultural Marketing and Food Storage}

Bihar took the unique step of repealing the APMC Act in 2006 and, at present, there is no legislation regulating agricultural marketing. Kishore et al. (2014) in their study highlight that the post-APMC era in Bihar seems to have been a mixed experience for different stakeholders. 
Post APMC reform, the liberal market environment favours processing industries as they now have increased sourcing options without paying mandi taxes. Given that the food processing industry is at a very nascent stage in Bihar, these benefits are limited. As at the national level, only two to three per cent of total fruits and vegetables go through any kind of processing. However, for Bihar, food processing is much more important as the high value segment dominates agricultural output.

The state has not been active in the procurement of wheat and paddy at the minimum support price (MSP) with the result that the farm harvest price (FHP) has been in most years lower than the MSP (Fig. 8.14). One of the main reasons for the lack of initiative in procurement is the deficit in storage facilities in the state. Bihar produces around $8.4 \%$ of total vegetables in the country and around $4.8 \%$ of fruits but only four per cent of total cold storages in India are in Bihar. The shortcomings in the quality and quantity of power supply in the state have also contributed to the closure of cold storages. In order to bolster cold storage construction, the Bihar Government has initiated a cold storage scheme under which cold storages with a capacity of 5-10 thousand tonnes can avail of a subsidy of $30 \%$ on capital expenditure.

The state has ambitious plans to expand the storage of food-grains, the lack of capacity in which has been identified as one of the main impediments in increasing procurement. The estimated capacity needed is 12.61 lakh metric tonnes against which it had a storage capacity of 6.98 lakh metric tonnes at the beginning of the year 2016-17. The plan was to make good the shortfall of 5.63 lakh metric tonnes during 2016-17 and to add further capacity of 60,000 metric tonnes every year up to $2020-21$.

\subsection{Sources of Agriculture Growth in Bihar}

In order to study the sources of agriculture growth in Bihar, we calculate the share of the value of output from different segments as a percentage of the total value of output from agriculture and allied activities (GVOA) (at current prices). Further, to analyse the sources of agricultural growth, we have decomposed the year-on-year growth in GVOA by taking the absolute year-on-year difference in GVOA from each segment as a proportion of the previous year's GVOA. Additionally, we look at production trends and growth rates reflecting sectoral performance. Given the high volatility in Bihar's agricultural growth, this exercise is important to throw light on the sub-sectors that are driving agricultural growth.

The share of value of output from different segments as a percentage of the total value of output from agriculture and allied activities (GVOA) (at current prices) has been shown in Fig. 8.15. The figure highlights how the sectoral composition of Bihar's agrarian economy has changed between TE 2002-03 and TE 2015-16. The shares of livestock, fishery and sugar have made gains while those of cereals and 


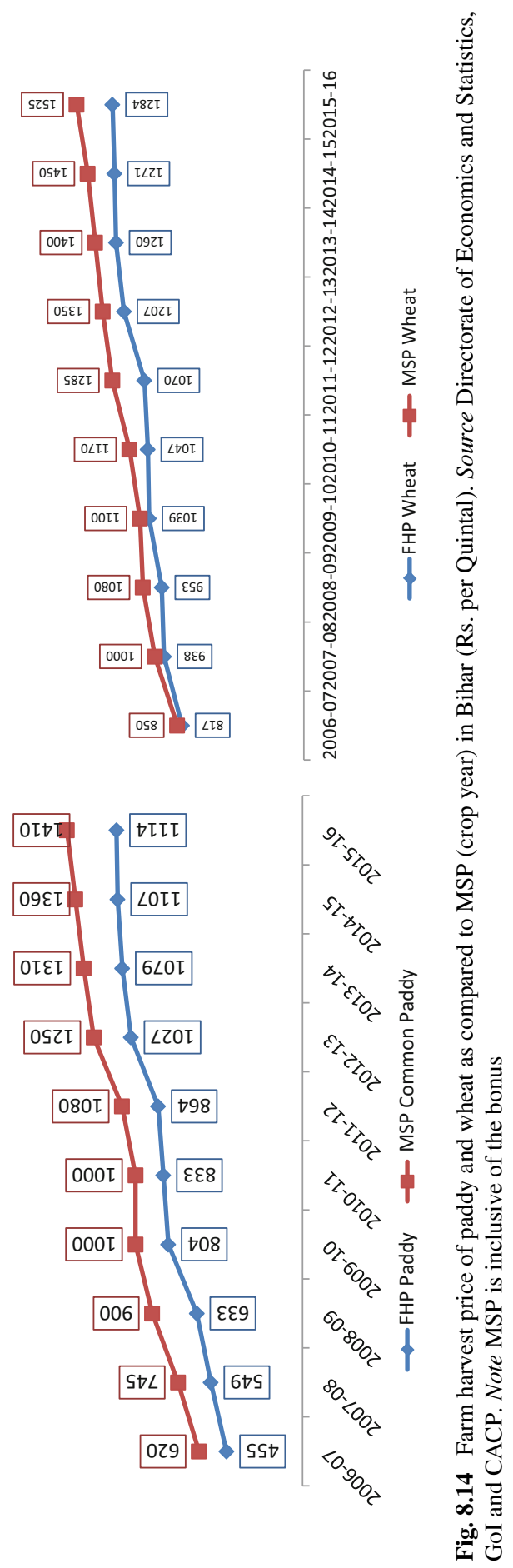




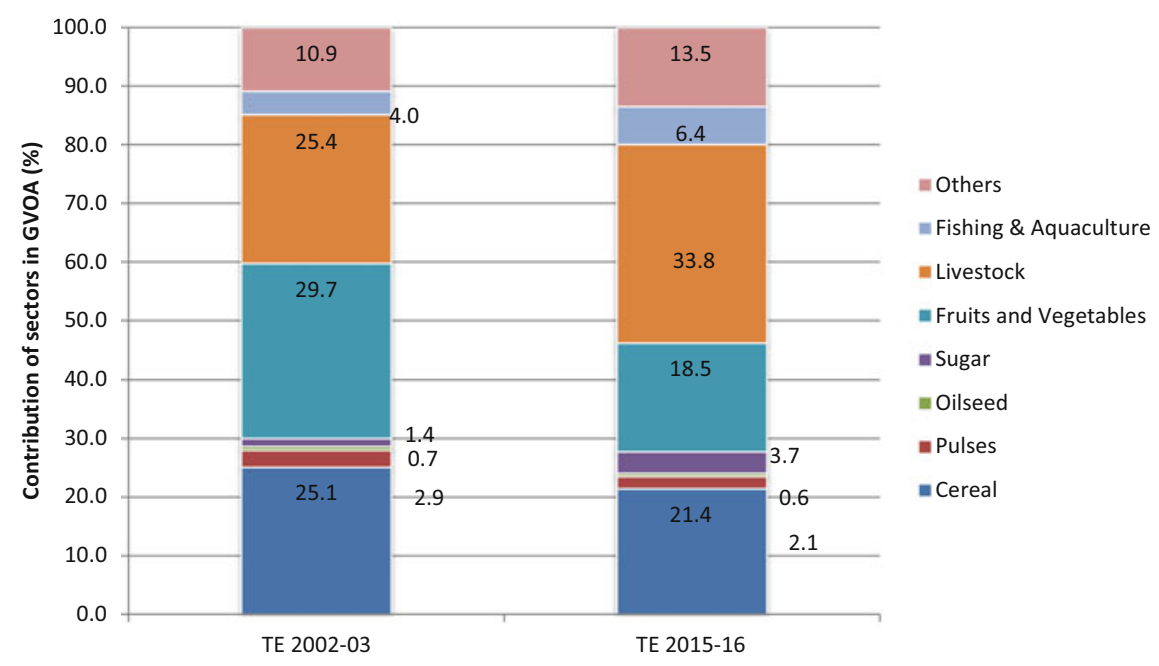

Fig. 8.15 Sector-wise shares in total value of output from agriculture and allied activities (at current prices). Source Government of India, State-wise Estimates of Value of Output from Agriculture and Allied Activities, various years. Note Others include drugs and narcotics, condiments and spices, other crops, kitchen garden, by-products, forestry and logging

fruits and vegetables have lost somewhat, although they remain important. The share of pulses, already low at $3 \%$ at the beginning of the period, has also declined to $2 \%$.

The GVOA grew annually at average 5.8\% in the period from 2000-01 to 201516. Livestock accounted for the highest contribution (37\%), followed by fruits and vegetables $(20 \%)$, cereals $(15 \%)$ fishing and aquaculture $(8 \%)$ and forestry and logging (8\%) (Fig. 8.16).

Figure 8.17 shows the changes in the sectoral composition of the GVOA for the period between 1999-00 and 2015-16. The share of livestock in GVOA has been increasing rapidly since 2003-04, affecting the shares of fruits and vegetables as well as of food grains.

\section{Production and productivity of major crops}

Bihar is endowed with abundant groundwater resources and fertile soil, which help farmers produce a variety of cereal and non-cereal crops, including fruits and vegetables. Table 8.2 shows the production and productivity of major crops from TE 200304 to TE 2017-18. The production and productivity of rice, maize and sugarcane have risen substantially. Wheat has lagged behind with lower growth, while the production of pulses has registered negative growth. One of the main reasons for the lower productivity of wheat is the delayed sowing time in Bihar.

The acreage and production under sugarcane have increased, underlining the suitability of the climate and soil in this state for the crop. However, the yield of sugarcane at $68.4 \mathrm{mt} / \mathrm{ha}$, which is lower than the national average of $73.3 \mathrm{mt} / \mathrm{ha}$ in TE $2017-$ 18 , has been a problem. In an effort to increase the yield, the state government has 


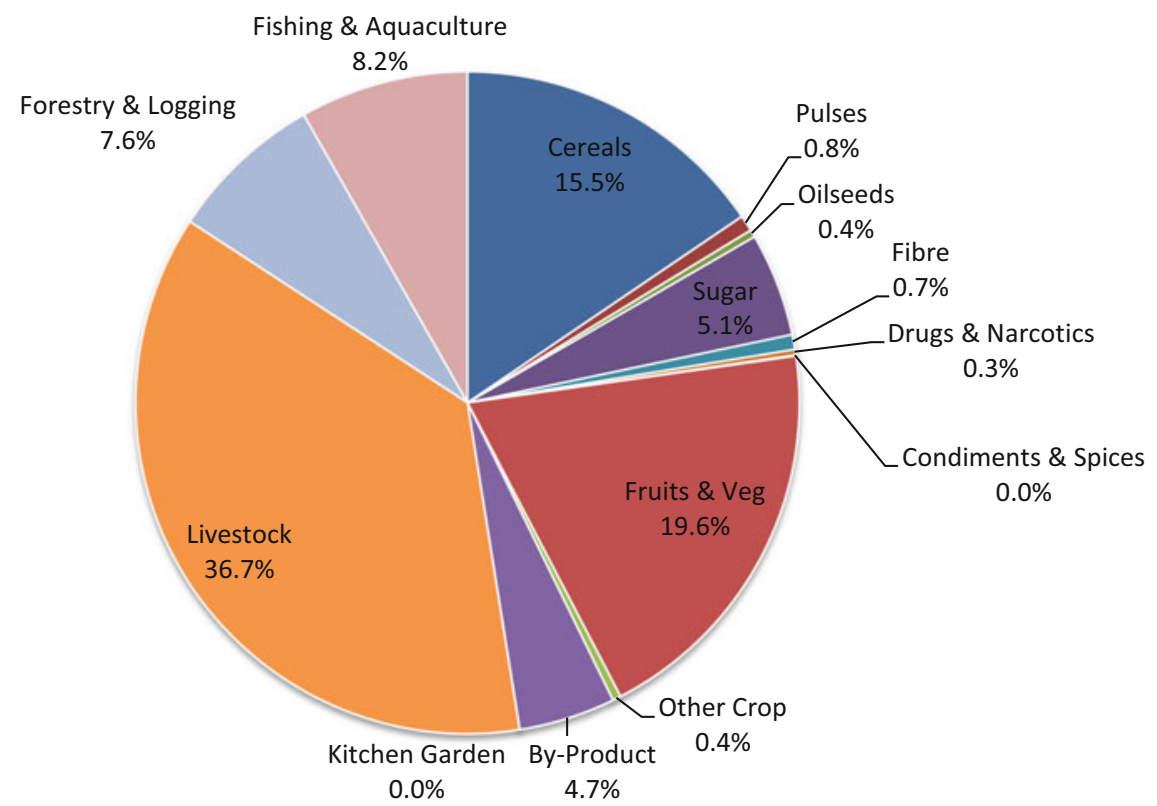

Fig. 8.16 Growth of value of output coming from each segment (2000-01 to 2015-16). Source Calculated by authors

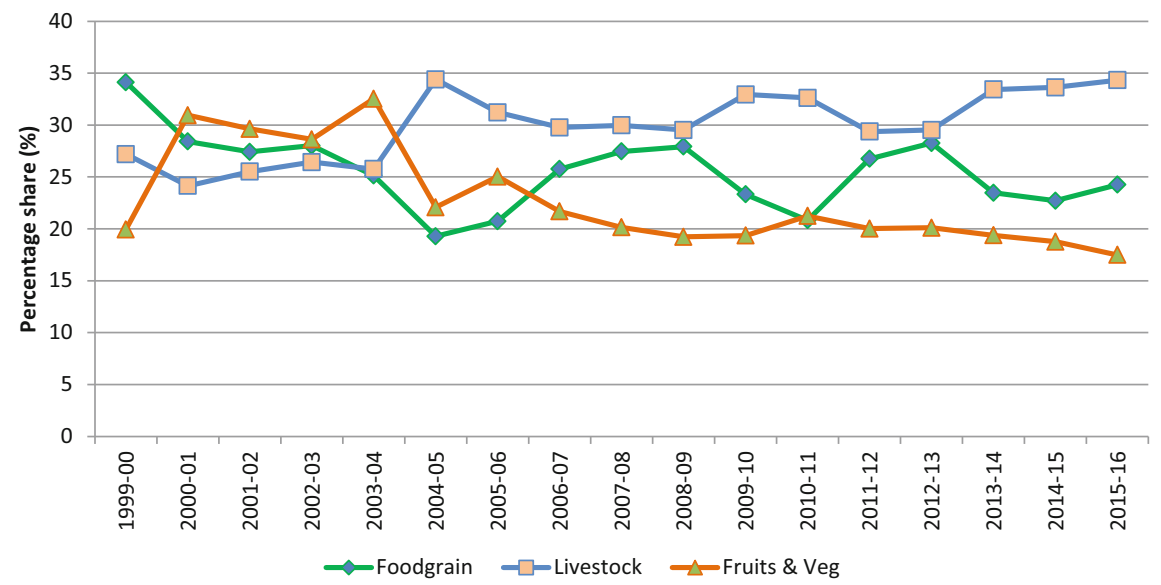

Fig. 8.17 Sectoral composition of agricultural and allied activities in GVOA from 2001-02 to 2015-16 (\%). Source Government of India, State-wise estimates of value of output from agriculture and allied activities, various years 
Table 8.2 Production and productivity of major crops

\begin{tabular}{l|l|l|l|l|l|l}
\hline \multirow{2}{*}{ Crop } & \multicolumn{3}{|l|}{ Production (million tonnes) } & \multicolumn{3}{l}{ Productivity metric tonnes (mt/ha } \\
\cline { 2 - 7 } & TE 2003-04 & TE 2017-18 & CAGR (\%) & TE 2003-04 & TE 2017-18 & CAGR (\%) \\
\hline Total cereal & 10.7 & 16.5 & 2.9 & 1.7 & 2.5 & 2.7 \\
\hline Rice & 5.3 & 7.7 & 2.6 & 1.5 & 2.4 & 3.2 \\
\hline Wheat & 4.0 & 5.6 & 2.2 & 1.9 & 2.3 & 1.1 \\
\hline Maize & 1.4 & 3.2 & 5.7 & 2.3 & 4.1 & 3.9 \\
\hline $\begin{array}{l}\text { Other coarse } \\
\text { cereals }\end{array}$ & 0.1 & 0.0 & -3.3 & 0.9 & 1.1 & 1.0 \\
\hline Pulses & 0.6 & 0.5 & -1.3 & 0.8 & 0.9 & 0.6 \\
\hline Oilseeds & 0.1 & 0.1 & 0.5 & 0.8 & 1.1 & 1.9 \\
\hline Sugarcane & 4.7 & 18.0 & 9.4 & 43.2 & 68.4 & 3.1 \\
\hline
\end{tabular}

Source Directorate of Economics and Statistics, GOB

supported sugarcane farmers by giving them a subsidy of Rs. 135 per quintal on the purchase of certified seeds and an incentive amount for inter-cropping with sugarcane under the National Food Security Mission (NFSM) programme. The state government has also taken the initiative to provide training to farmers to use improved varieties of seeds. The state provides a subsidy in terms of the distribution of plant protection chemicals at the rate of $50 \%$ of the total cost or a maximum of Rs. 200 per ha to sugarcane producers. The government has also provided Rs. 25,000 per ha for the production of foundation seeds (Economic Survey of Bihar, 2017).

\section{Fruits and Vegetables}

The production of a variety of fruits and vegetables in the state provides a strong base for high-value agriculture and the food processing industry. This industry can flourish only if there is efficient supply of power. Within the fruits and vegetable segment, vegetables constitute a larger share. In terms of acreage, the state devotes around $11 \%$ of its gross cropped area to vegetable production, which is way above the national average of 5.0\%. In TE 2017-18, Bihar was the fourth largest vegetable producer (8.4\%), after West Bengal, Uttar Pradesh and Madhya Pradesh. Potato is the most important vegetable grown in the state with around $38 \%$ of vegetable area dedicated to the crop. Apart from potato, the other main vegetables grown in Bihar are cauliflower, okra, brinjal, onion, tomato and cabbage.

The trend of production and productivity of the full range of major vegetables grown in the state is given in Table 8.3. The state was the third-largest producer of potato in TE $2017-18$ with $31.4 \%$ of the cropped area under vegetables accounted for by potato. In TE 2017-18, potato yield in Bihar was around $21.3 \mathrm{mt}$ per ha as compared to the all-India average of $23.3 \mathrm{mt}$ per ha.

As Table 8.3 shows, Bihar's productivity in okra, brinjal and onion as well as in vegetables as a group are higher than the national average. However, it is lower in cauliflower, tomato and cabbage, apart from potatoes to which we have already 
Table 8.3 Production and productivity of vegetables

\begin{tabular}{|c|c|c|c|c|c|c|}
\hline \multirow[t]{2}{*}{ Crop } & \multicolumn{3}{|l|}{ Bihar } & \multicolumn{3}{|l|}{ India } \\
\hline & TE 2007-08 & TE 2017-18 & CAGR $(\%)$ & TE 2007-08 & TE $2017-18$ & CAGR $(\%)$ \\
\hline \multicolumn{7}{|c|}{ Production (million tonnes) } \\
\hline Potato & 5.8 & 6.8 & 1.5 & 30.7 & 47.8 & 4.1 \\
\hline Cauliflower & 1.0 & 1.0 & 0.0 & 5.6 & 8.4 & 3.8 \\
\hline Cabbage & 0.6 & 0.7 & 1.4 & 8.7 & 8.8 & 0.1 \\
\hline Onion & 1.0 & 1.2 & 1.7 & 19.8 & 22.2 & 1.0 \\
\hline Tomato & 0.9 & 1.0 & 1.0 & 10.0 & 19.7 & 6.4 \\
\hline Brinjal & 1.1 & 1.2 & 0.8 & 9.5 & 12.6 & 2.6 \\
\hline $\begin{array}{l}\text { Okra } \\
\text { (Bhindi) }\end{array}$ & 0.7 & 0.7 & 0.0 & 4.1 & 5.9 & 3.4 \\
\hline $\begin{array}{l}\text { All } \\
\text { vegetables }\end{array}$ & 13.7 & 14.9 & 0.8 & 117.4 & 177.2 & 3.8 \\
\hline \multicolumn{7}{|c|}{ Productivity metric tonnes/ha } \\
\hline Potato & 18.5 & 21.3 & 1.3 & 18.1 & 22.3 & 1.9 \\
\hline Cauliflower & 16.5 & 15.2 & -0.7 & 18.6 & 19.0 & 0.2 \\
\hline Cabbage & 16.5 & 17.7 & 0.6 & 21.9 & 22.4 & 0.2 \\
\hline Onion & 19.8 & 23.1 & 1.4 & 14.2 & 17.0 & 1.6 \\
\hline Tomato & 18.5 & 21.5 & 1.4 & 19.2 & 25.1 & 2.5 \\
\hline Brinjal & 20.4 & 20.3 & 0.0 & 17.3 & 17.9 & 0.3 \\
\hline $\begin{array}{l}\text { Okra } \\
\text { (Bhindi) }\end{array}$ & 12.6 & 13.4 & 0.6 & 10.8 & 11.8 & 0.8 \\
\hline $\begin{array}{l}\text { All } \\
\text { vegetables }\end{array}$ & 16.7 & 17.9 & 0.6 & 16.7 & 17.4 & 0.4 \\
\hline
\end{tabular}

Source National Horticulture Database, several issues

referred. Even in these three vegetables, Bihar seems to be closing the gap with the national average. Clearly, vegetable cultivation is an area of promise in Bihar.

Around $4 \%$ of its GCA is dedicated to fruit cultivation as compared to the national average of 3.2\%. Mango, banana, litchi and guava are the main fruits grown in Bihar. In TE 2017-18, around 51.0\% of the area under fruit cultivation was devoted to mango orchards, $11.9 \%$ to banana, $10.9 \%$ to litchi and $10.1 \%$ to guava. Bihar's productivity in fruit cultivation is around $14.9 \mathrm{mt}$ per ha, which is slightly higher than the national average of $14.6 \mathrm{mt}$ per ha. Of the fruits grown in the state, there has been robust growth in the production of banana and guava in recent years (Table 8.4). Bihar is the top litchi producing state in the country and the state contributes around $42.7 \%$ of total production. In terms of mango production, Bihar ranks fifth contributing around $8.9 \%$ of the total production. 
Table 8.4 Production and productivity of fruits

\begin{tabular}{|c|c|c|c|c|c|c|}
\hline \multirow[t]{2}{*}{ Fruits } & \multicolumn{3}{|l|}{ Bihar } & \multicolumn{3}{|l|}{ India } \\
\hline & TE 2007-08 & TE 2017-18 & CAGR (\%) & TE 2007-08 & TE 2017-18 & CAGR (\%) \\
\hline \multicolumn{7}{|c|}{ Production (million tonnes) } \\
\hline Banana & 1.1 & 1.5 & 2.9 & 21.0 & 30.1 & 3.3 \\
\hline Guava & 0.2 & 0.4 & 6.5 & 1.8 & 3.9 & 7.3 \\
\hline Litchi & 0.2 & 0.2 & 0.0 & 0.4 & 0.6 & 3.8 \\
\hline Mango & 1.1 & 1.8 & 4.6 & 13.4 & 20.0 & 3.7 \\
\hline Fruits & 3.3 & 4.5 & 2.9 & 59.5 & 93.4 & 4.2 \\
\hline \multicolumn{7}{|c|}{ Productivity metric tonnes/ha } \\
\hline Banana & 38.9 & 44.2 & 1.2 & 34.6 & 35 & 0.1 \\
\hline Guava & 8.3 & 13.6 & 4.6 & 10.6 & 15.3 & 3.4 \\
\hline Litchi & 7.3 & 6.5 & -1.0 & 7.3 & 6.6 & -0.9 \\
\hline Mango & 8.0 & 12.0 & 3.8 & 8.0 & 9.0 & 1.1 \\
\hline Fruits & 11.4 & 14.9 & 2.5 & 11.6 & 14.6 & 2.1 \\
\hline
\end{tabular}

Source National Horticulture Database, several issues

\section{Livestock}

Animal husbandry plays an important role in Bihar's economy by providing employment and income opportunities apart from crop cultivation. The state is endowed with vast resources of livestock and poultry. As discussed above, it is evident that the livestock sector contributed $33 \%$ to GVOA in TE 2015-16. Figure 8.18 shows

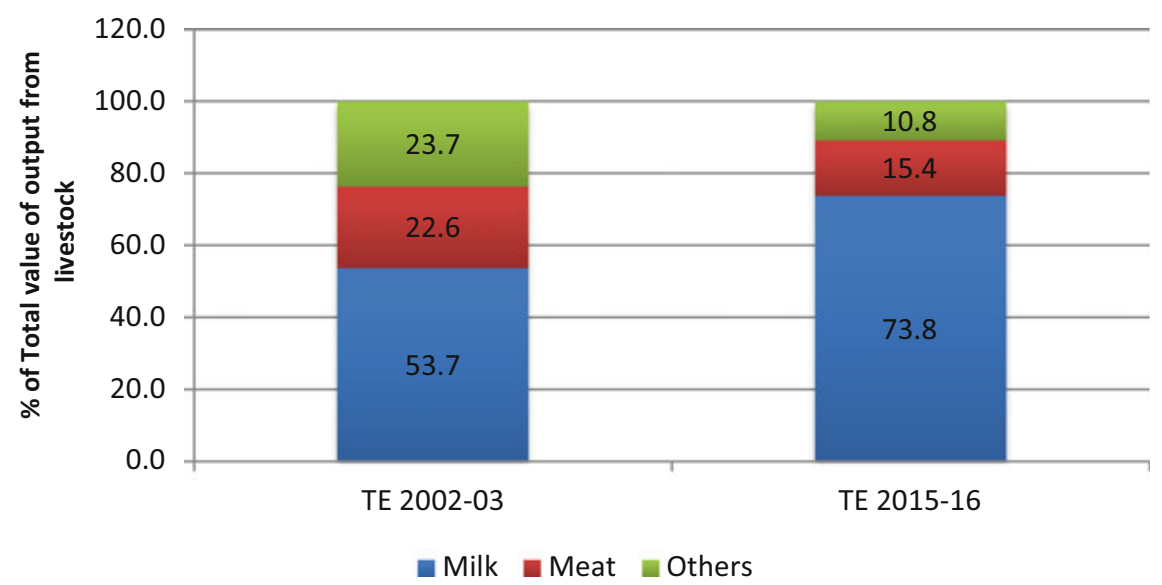

Fig. 8.18 Composition of livestock segment (percentage of total value of output from livestock sector). Source Government of India, State-wise Estimates of Value of Output from Agriculture and Allied Activities, various years 


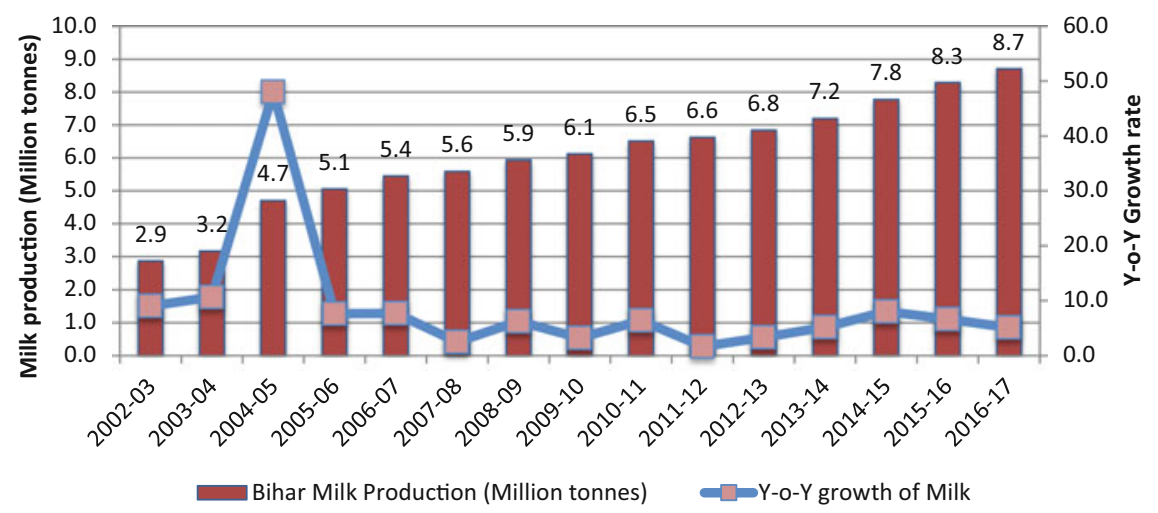

Fig. 8.19 Production of milk in Bihar (Million Tonnes). Source Economic Survey of Bihar, various years

the changing composition of livestock in Bihar from TE 2002-02 to TE 2015-16. The share of milk in livestock increased from $53.7 \%$ in TE $2002-03$ to $73.8 \%$ in TE 2015-16.

\section{Milk and Meat}

As evident from the earlier discussion, milk is an important segment of the livestock sector and has also led to the changing composition of livestock. The production of milk has increased from 2.9 million tonnes in 2002-03 to 8.7 million tonnes in 2016-17. Looking at the growth rate of milk, there is a significant sharp rise in the production of milk in the year 2004-05 (Fig. 8.19). This apparent sharp rise was due to the fact that the livestock census was conducted in 2003 in the state, which estimated that the number of livestock was much higher than earlier projections had suggested. It is evident that the value of output from livestock was underestimated earlier. However, the state has low productivity in milk, which was about $0.8 \mathrm{mt}$ per lactating animal in TE 2016-17. Despite high growth in milk production, the state has a low proportion of genetically superior cattle, which is a pre-requisite for higher milk productivity.

Exotic/cross-bred cows have superior genetic potential to yield proportionately higher productivity compared to native breeds. On average, a cross-bred cow yields 7.4 L a day nationally, but in Punjab, a typical cross-bred cow yields about $12.0 \mathrm{~L}$ a day while in Bihar, it is only 6.5 L a day. This means that cross-bred yield in Bihar is almost half the yield in Punjab (Table 8.5). The production trait of milk-producing cattle in Punjab is better than in Bihar because of the use of germplasm from superior breeds in cross-breeding in the former.

The state-run Bihar State Milk Co-operative Federation (COMFED) works on a similar three-tier model as Anand in Gujarat. COMFED has played a significant role in the growth of the dairy industry (Economic Survey of Bihar 2017-18). There were 20.7 thousand milk co-operative societies in 2016-17. In 2016-17, milk procurement 
Table 8.5 Species wise yield of in-milk animals (Ltr/day) in select states

\begin{tabular}{l|l|l|l|l|l|l}
\hline \multirow{2}{*}{ State } & \multicolumn{2}{|l|}{} & $2016-17$ \\
& Crossbred & Local cow & Buffalo & Crossbred & Local cow & Buffalo \\
\hline Bihar & 5.5 & 1.7 & 3.4 & 6.5 & 3.3 & 4.3 \\
\hline Punjab & 8.7 & 3.1 & 6.8 & 12.0 & 7.0 & 9.5 \\
\hline India & 6.3 & 1.9 & 4.3 & 7.4 & 3.5 & 5.9 \\
\hline
\end{tabular}

Source Basic Animal Husbandry Statistics, DAD\&F, GoI

per functional dairy declined to 108.6 kilolitres as compared to 124.2 kilolitres in 2015-16. COMFED processes only $9-10 \%$ of the milk produced and another $2-$ $3 \%$ is processed in the organised private sector. There is still a need to improve procurement and processing of milk in the state. The state government has several schemes like medical treatment of animals, artificial insemination, sterilisation and free distribution of fodder to encourage the growth of this sector. Under "Samagra Gavya Vikash Yojana", the state government has sanctioned an amount of Rs. 80 crore to establish dairy units.

The changing composition of the livestock sector highlights the declining share of meat over time. Figure 8.18 shows that the share of meat in GVOA has declined from $22.6 \%$ in TE 2002-03 to $15.3 \%$ in TE 2015-16. The CAGR of meat production for the period from 2007-08 to 2016-17 was around 6.7\%. Figure 8.20 shows meat production in Bihar from 2007-08 to 2016-17. Within total meat production, mutton and pork account for the two largest shares followed by buffalo meat and poultry. The lack of modern abattoirs with processing facilities having due forward and backward linkages has slowed the growth of value-added products in this sector.

Poultry's share in total meat production is only 16.3\% (2016-17). However, between 2008-09 and 2012-13, poultry has grown at the fastest rate as compared to other animal meats in Bihar due to the robust expansion of poultry farms and hatcheries. As per the 19th Livestock Census (2012), Bihar's backyard poultry shrank at a CAGR of $1.7 \%$ in the period 2007 and 2012. This is analogous to the national

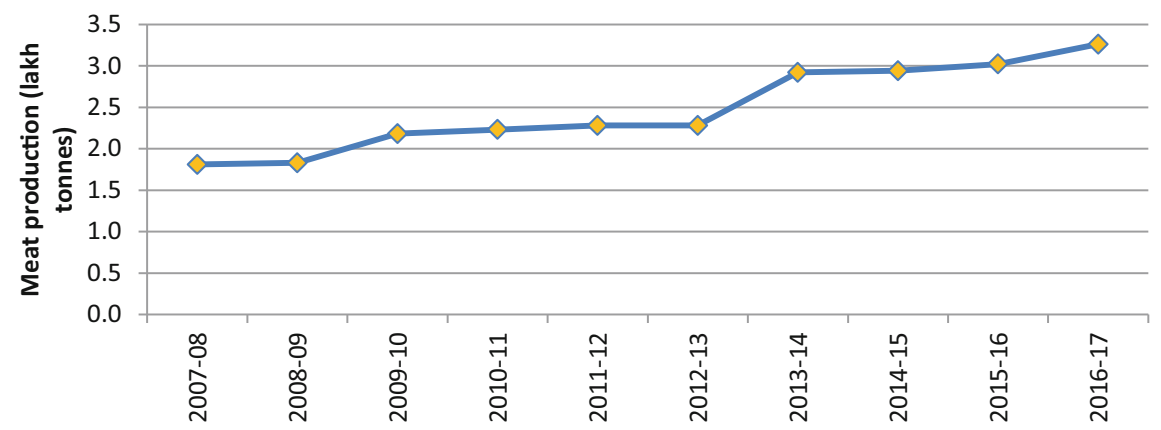

Fig. 8.20 Production of meat in Bihar. Source Department of Animal husbandry, GOB 


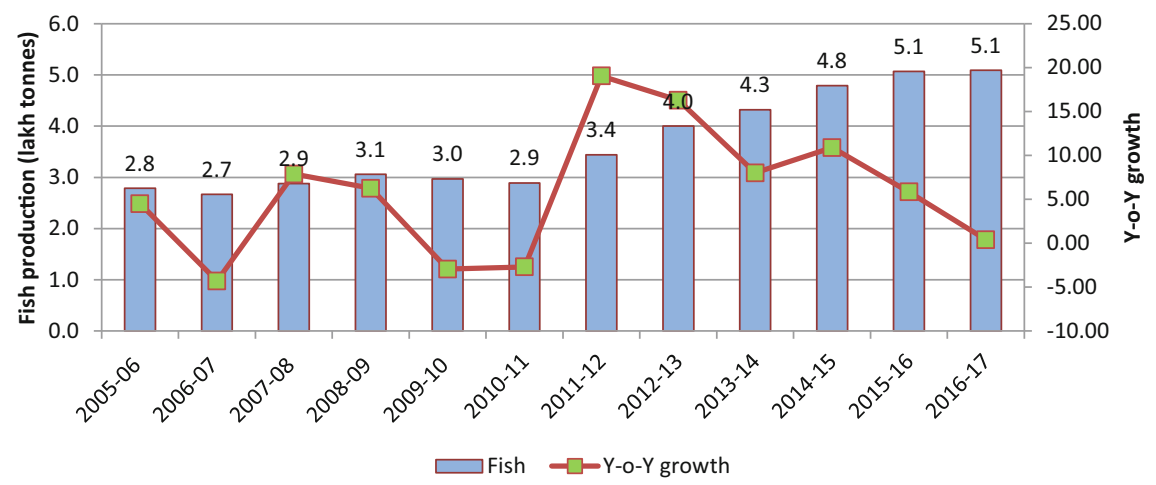

Fig. 8.21 Fish production in Bihar. Source Department of Animal husbandry, GOB

trend, which shows a fall in backyard poultry, and an increase in farms and hatcheries. In Bihar, the number of poultry birds in broiler farms increased from 3.1 million to 5.1 million in this period, a CAGR of $7.8 \%$, as compared to the national average of $6.3 \%$. Bihar has also recorded a robust expansion in duck population in duck farms.

\section{Fisheries}

Bihar is endowed with 273.3 thousand ha of area underwater and $3200 \mathrm{~km}$ of river length. This gives the state an advantage in fish production. Fish production has gradually increased from 2.8 lakh tonnes in 2005-06 to 5.1 lakh tonnes in 2016-17 (see Fig. 8.21). In terms of GVOA, the share of fish increased from $4.0 \%$ in TE 2002-03 to $6.4 \%$ in TE 2015-16. However, the per capita availability of fish in the state stands at $7.7 \mathrm{~kg}$ against the national average of $10.0 \mathrm{~kg}$. In view of the fact that the fisheries sector has huge potential in providing gainful employment, the state has provided subsidies for the establishment of fish feed mills, construction of fish seed hatcheries, renovation of ponds and distribution of vehicles for fish marketing. About 121 fish seed farms and 10 private hatcheries by the government are working to meet the growing demand for fish seeds.

\subsection{Drivers of Agricultural Growth: Econometric Analysis}

The literature emphasises that the drivers of agricultural growth are factor inputs such as HYV adoption ratio, irrigation, fertiliser consumption, farm mechanisation and agricultural extension. The other factors that affect agricultural growth, apart from factor inputs, are price incentives and rural infrastructure. The study analyses the impact of different factor inputs in agriculture, rural infrastructure and incentives on GSDPA (at 2004-05 prices) for the period from 2001-02 to 2015-16 using ordinary least squares. The correlation matrix and description of the variables are shown in Tables 8.8 and 8.9 in the Annexure. 
In this study, we have used irrigation as a representative of inputs used in agriculture, terms of trade between agriculture and industry, diversification towards milk and total road density, which is used as representative of infrastructure. The correlation matrix shows that GSDPA has a significant and positive correlation with irrigation, total road density, terms of trade and diversification towards milk.

The function is defined as follows:

$$
Y_{t}=\beta_{o}+\beta_{1} X_{1}+\beta_{2} X_{2}+\beta_{3} X_{3}+\beta_{4} X_{4}+\cdots
$$

where $X_{1}$ is irrigation ratio (IRR); $X_{2}$ is total road density; $X_{3}$ is terms of trade (ToT) between agriculture and industry and $X_{4}$ is diversification towards milk production measured as the share of milk in GVOA.

The log value of GSDPA at 2004-05 prices is the dependent variable. However, due to the high correlation among the explanatory variables, we have specified three different double-log models to gauge the relationship between agricultural gross domestic product (GDP) and drivers of agricultural growth (Table 8.6). We have run the model with different variables and have presented only those variables that have a significant effect on agricultural GDP.

In Model 1, irrigation has a positive and significant impact on agricultural GDP; every one per cent increase in the share of irrigated area increases agricultural GDP by $1.8 \%$. However, the ToT between agriculture and industry shows no relationship with agricultural GDP. In Model 2, total road density has a positive and significant impact on agricultural GDP; every one per cent increase in road density increases agricultural GDP by $0.44 \%$ and ToT shows no significant relationship. Model 3 indicates that a one per cent increase in ToT increases agricultural GDP by $0.6 \%$ and diversification towards milk impacts agricultural GDP by $0.53 \%$.

Table 8.6 Model estimation: ordinary least squares (2001-02 to 2015-16)

\begin{tabular}{l|l|l|l}
\hline Dependent variable: GSDPA & Model 1 & Model 2 & Model 3 \\
\hline IRR (share of irrigates area in GCA) & $1.88^{* *}$ & & \\
\hline Total road density ( km/100 km sq of area) & 0.11 & $0.44 * * *$ & \\
\hline Milk (share in GVOA) & & & $0.53 * *$ \\
\hline ToT (Agricultural deflator/industry deflator) & & 0.14 & $0.60^{*}$ \\
\hline Constant & $2.8 * * *$ & $5.4 * * *$ & $5.7 * * *$ \\
\hline R-sq & 0.8 & 0.7 & 0.5 \\
\hline Observation & 15 & 15 & 15 \\
\hline
\end{tabular}

Source Calculated by authors

Note $* * *$ significant at $1 \%$ level $(p$-value $<0.01)$; **significant at $5 \%$ level $(p$-value $<0.05)$;

*significant at $10 \%$ level $(p$-value $<0.1)$ 


\subsection{Assessment of Budgetary Allocation to Agriculture and Allied Activities}

The present section will evaluate the budgetary expenditure for the last three financial years-FY 2016-17 (actual), FY 2017-18 (RE) and FY 2018-19 (BE) to assess if there has been a correction in the historically overwhelming budgetary support to crop production and, within crops, to grain production. Changing dietary patterns towards the consumption of non-staples and the potential that other sub-sectors of agriculture hold in terms of both catering to changing tastes and to augment farm incomes indicate the need to reverse the historical trend and to increase budgetary allocations to the horticulture (F\&V) and livestock sectors.

The broad budgetary allocation on agriculture and allied activities is shown in Fig. 8.22. The graph shows that crop husbandry constitutes the largest share of budgetary allocations $(51.7 \%)$ followed by animal husbandry and dairy development (10.9\%) and agricultural research and education (7.8\%) for the FY 2018-19 (BE).

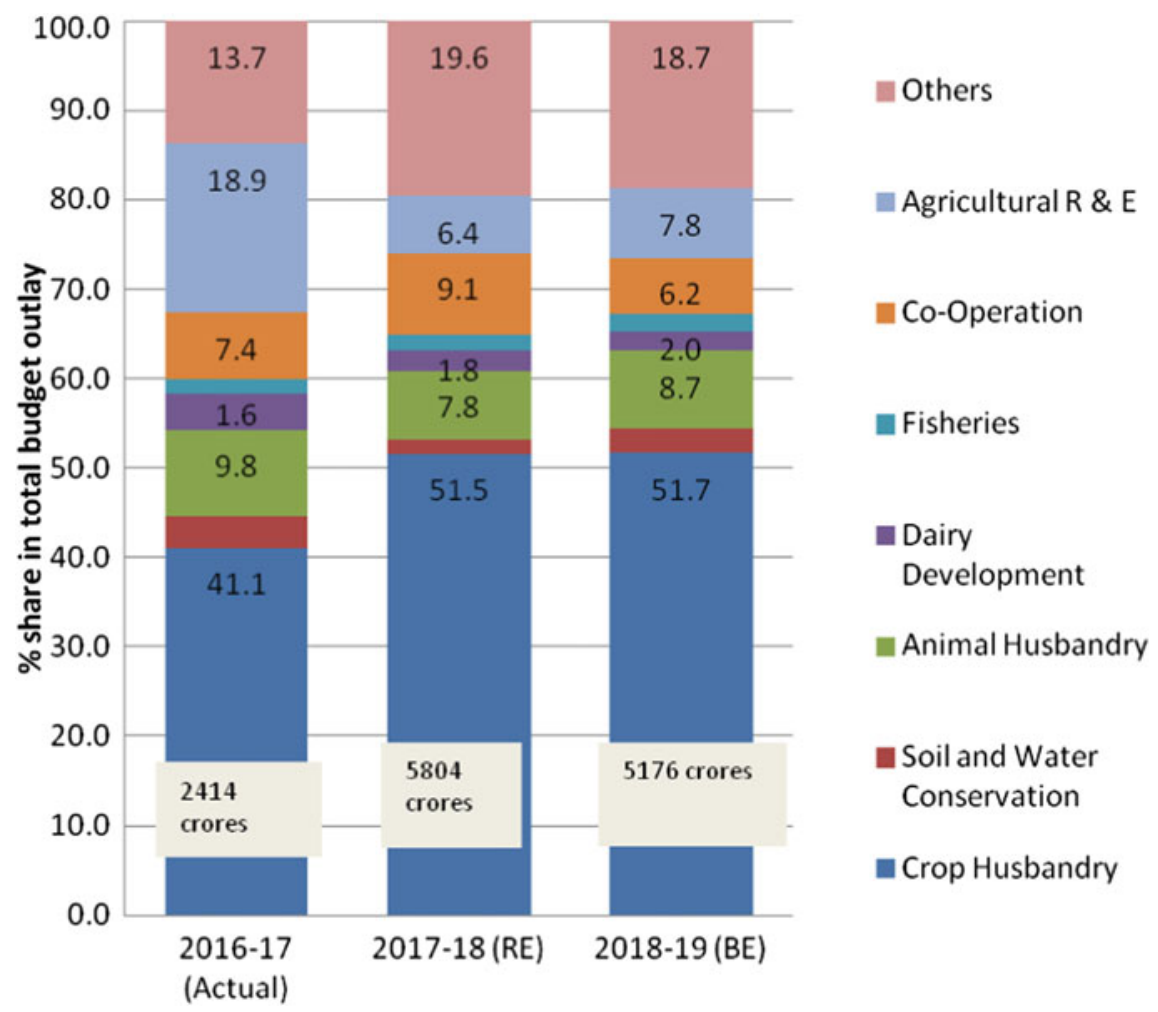

Fig. 8.22 Allocation to broad heads as a share of the total allocation to agriculture and allied activities. Source Finance Department, Government of Bihar 


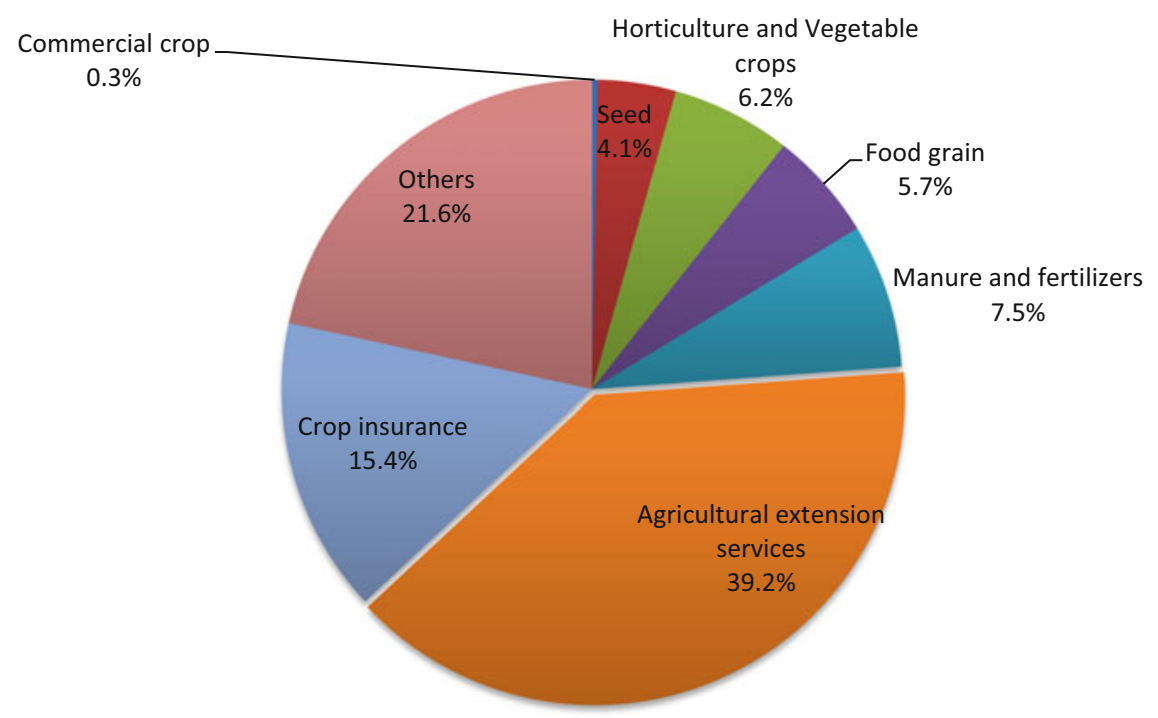

Fig. 8.23 Allocation to broad heads as a share of the total allocation to crop husbandry in TE 2018-19. Source Finance Department, Government of Bihar

Crop husbandry comprises food grains, horticulture and vegetables and commercial crops. It also includes expenditure on support services that apply to all segments such as agricultural extension services, crop insurance, seeds, manure and fertilisers, etc. The major allocations under crop husbandry are made for agriculture extension services $(39 \%)$ as well as crop insurance $(15.4 \%)$ followed by manure and fertilisers (7.5\%) in TE 2018-19 (Fig. 8.23).

Figure 8.24 provides the budgetary allocation for different sub-sectors in the agriculture and allied activities sector.

Of course, it cannot be expected that the share of budgetary expenditure on various segments will correspond to the share of the segment in GVOA. Even so, when we compare the two shares, we find that the budgetary expenditure on livestock is well below the share of this segment in the GVOA. Similarly, there is a large gap between the share of horticulture and vegetables in GVOA (18.5\%) and the budgetary allocation (2.8\%) in TE 2018-19. The same is the case with commercial crops (oilseeds, sugar and jute fibre) where the share in GVOA is 5\% while the budgetary allocation is $0.1 \%$. Also, while the fisheries sector contributes $6.4 \%$ in GVOA, the budgetary allocation is only $1.8 \%$. Here, we would like to note only that there would seem to be scope for introducing support schemes with respect to those segments in which the budgetary allocation is relatively lower than the contribution to the GVOA. 

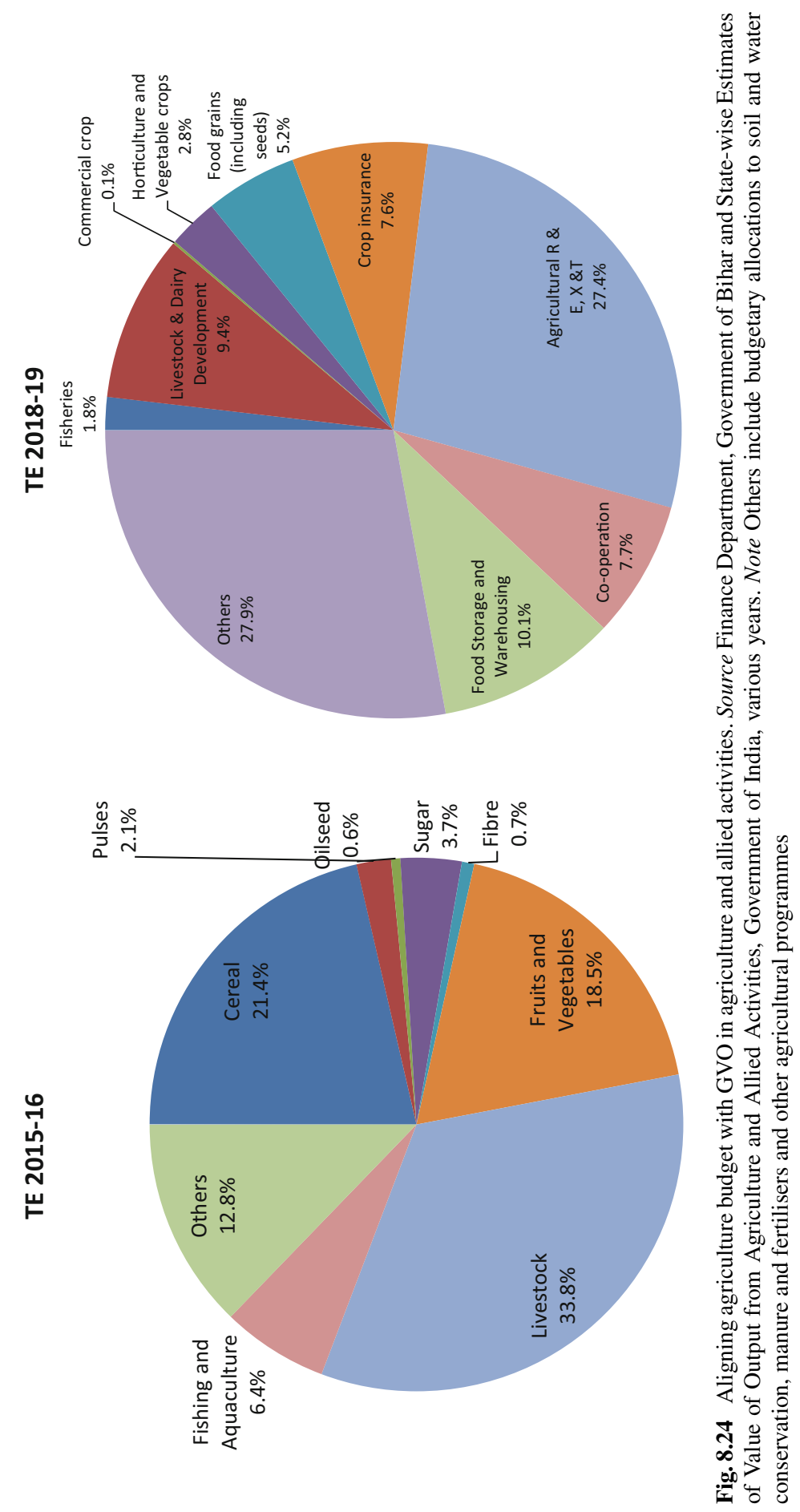
Table 8.7 Budgetary allocation (capital outlay) for infrastructure (in crore)

\begin{tabular}{l|l|l|l}
\hline Budget allocation & $2016-17$ (Actual) & $\begin{array}{l}2017-18 \text { (Revised } \\
\text { estimate) }\end{array}$ & $\begin{array}{l}2018-19 \text { (Budget } \\
\text { estimate) }\end{array}$ \\
\hline $\begin{array}{l}\text { Irrigation (including } \\
\text { major, medium and } \\
\text { minor irrigation) }\end{array}$ & 896.2 & 1605 & 1107.7 \\
\hline Flood control & 899.5 & 1288.6 & 1502.6 \\
\hline $\begin{array}{l}\text { Irrigation and flood } \\
\text { control }\end{array}$ & 1795.7 & 2893.6 & 2610.3 \\
\hline Power projects & 5738.6 & 6958.6 & 5424.8 \\
\hline Road and bridges & 5325.5 & 5876.0 & 5473.2 \\
\hline
\end{tabular}

Source Finance Department, Government of Bihar

We cannot expect the expenditure by the state on food grains to match the share of cereals in the GVOA. The production of cereals is supported heavily by the central government through input subsidies (fertilisers and credit); further, the state subsidies on irrigation and power do not get reflected in the budgetary allocation. Low procurement ratio in the state is due to lack of storage facilities which the state is endeavouring to build by allocating $10 \%$ of the agricultural budget to food storage and warehousing.

Equally important to the budgetary allocation for the agricultural programmes is the capital outlay on infrastructure, irrigation, power and roads. Table 8.7 gives details of budgetary allocations under these heads. More than $65 \%$ of irrigation is provided by tube wells, which are dependent on power supplies. We have seen that, in the past, there was acute difficulty in terms of the quality and quantity of power supplies to agriculture and that the state has been active in recent years in improving the power infrastructure. This has been fully reflected in the budgetary allocation to this sector.

In surface irrigation, the maximum capital outlay has been provided to major irrigation projects. It is observed that flood control projects take away a large proportion of the total funds available under irrigation and flood control.

The state has not lagged behind in the budgetary allocation for roadways including rural roads. The centrally sponsored Pradhan Mantri Gram Sadak Yojana (PMGSY) has been supplemented by state schemes. We do not have figures of the share of surfaced roads for the last three years to be able to confirm the physical achievement in these years. However, we have seen that the share of surfaced to total road had already increased from $47.2 \%$ in $2011-12$ to $59.8 \%$ in $2015-16$. 


\subsection{Policy Recommendations}

The study recommends the following policies required to increase agricultural growth as well as farm income in the state.

\section{Volatility in the Agricultural Sector: Flood and Drought Protection}

Agricultural growth in Bihar has been volatile which affects agricultural productivity. The huge endowment of water resources makes the state flood-prone, especially in the northern part. Nearly $73 \%$ of the northern part is affected by floods whereas the southern part of the state is drought-prone. This requires increased public investment in flood protection in the northern part and watershed management and rainwater harvesting in drought-prone areas. Given the criticism of constructing embankments as a flood protection measure, the state government has advocated a move towards the rehabilitation of natural drainage systems. The new strategy requires planning and investment by the state government along with social mobilisation and participation of civil society organisations.

\section{Utilisation of Ultimate Irrigation Potential}

Bihar has so far actualised $55.4 \%$ of the ultimate irrigation potential of major and medium irrigation projects and $63.7 \%$ of minor irrigation potential. The government needs to increase investment in both surface water and groundwater irrigation. The current irrigation ratio of $68.7 \%$ (TE 2014-15) is relatively high compared to most other states but we have to remember that there are huge population pressure and a high level of rural poverty in the state. The state needs to expand agricultural production substantially in order to provide a livelihood to the rural population. In order to achieve higher agricultural production, the state needs more irrigation. A higher irrigation ratio will facilitate higher crop intensity and will increase production.

\section{Increase Power Intensity in the Agriculture Sector}

More than $65 \%$ of irrigation is provided by groundwater through tube wells, which have to use diesel because of the poor quality and quantity of power available for agriculture. The state has already undertaken an extensive programme to bolster infrastructure for the transmission and distribution of power and there has been good progress in the last two to three years. Funds have been made available by the Government of India under DDUGJY and the state has separately availed a loan from the ADB. The implementation of these programmes will play a critical road in Bihar's agricultural development. Availability of power will also provide a stimulus also to the food processing industry.

\section{Popularise the Use of Solar Pumping Sets}

The state needs to popularise the use of solar pumping as an alternative to dependence on power supply from the grid especially in North Bihar, which has higher water tables and the bulk of shallow private tube wells. The Government of India has 
provided financial assistance of $30 \%$ of the project cost from the Ministry of New and Renewable Energy (MNRE) for the solar pumping programme for drinking water and irrigation. The state government has already installed 1000 solar pumps in 2015-16 under this scheme.

\section{Expansion of Dairy Co-operative Societies}

Milk contributed around $25 \%$ of the value of output from agriculture and allied activities in TE 201-16 and production increased at a CAGR of 7.6\% between 200203 and 2016-17. However, only $10 \%$ of the milk produced is being processed by COMFED and another $2-3 \%$ by other private players. There is considerable scope for expansion of dairy co-operative societies to increase the collection, processing and marketing of the milk produced in the state.

\section{Increase Milk Productivity}

Milk productivity in the state is lower than in states like Punjab. Health and reproduction management is crucial to increase productivity. Bihar needs to increase the proportion of cross-bred bovines and to use germplasm from superior breeds in cross-breeding. Furthermore, the state needs to make use of recent developments in technology and reduce the number of births of male calves to increase the share of milch animals in the herd. Additionally, the government should focus on utilising degraded and wasteland for quality fodder production, encourage short duration fodder crops in the periods between main crops and encourage efficient utilisation of available resources such as crop residue.

\section{Increase Investment in Surface Road Length}

The surface road density in Bihar is lower than in many states. The share of surfaced roads in total road length is only $59.8 \%$, lower than the national average as discussed in the chapter. The state government needs to increase investment in surface and allweather roads to improve connectivity and the movement of inputs and agricultural produce.

\section{Develop Marketing facilities}

Poor marketing facilities have led to the FCI procuring only a small proportion of food grains from Bihar. There is a need to expedite the construction of marketing infrastructure at designated locations to ensure that farmers benefit from the government's price policies. Markets also need to be connected with surfaced roads. Besides, farmers in Bihar need to integrate with the National Agriculture Markets-e-naman initiative launched by the GOI under which agricultural producers can fully participate in agricultural markets nationwide for better price discovery without intermediaries. 


\section{Scope for Poultry Development}

Poultry development in Bihar is in poor shape because of the lack of contract farming. Given the advantage that Bihar enjoys in the winter maize market, integrators should find it attractive to move into the state. In fact, if integrators expand their activities, there will also be scope for the establishment of maize processing units, which is currently insignificant, to reap the benefit of vertical integration in the maize value chain, and give a fillip to the poultry industry in Bihar. In the light of this, the state government needs to be pro-active in inviting well-known integrators to establish units in Bihar.

\section{Expansion of Fish Production}

The availability of a large number of fresh water bodies in the state provides a good basis for the development of fishery and the state government has taken a number of promotional measures to accelerate it. But the water bodies (sairats) are auctioned every year to private players, including fishermen's co-operatives. Yearly leases do not allow the lessees to invest in the water body and work for the long-term development of fisheries. If the water bodies are leased out for longer periods, say three to five years, this shortcoming can be overcome. The state government also plans to set up fish feed mills and construction of fish seed hatcheries at subsided rates. The government has initiated several schemes for fish farmers, which include the distribution of subsidised fish seed, loan for maintenance and renovation of private ponds at low-interest rates and provided free homes for fishermen.

\section{Facilitation of Agricultural Credit}

To facilitate the advancement of agricultural credit by commercial banks to farmers, it is critical that land surveys are completed quickly to revise and update land records to reflect current ownership.

\section{Annexure}

See Tables 8.8 and 8.9 . 
A. Hoda et al.

\begin{tabular}{|c|c|c|c|c|c|c|c|c|c|c|}
\hline 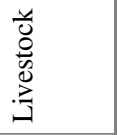 & & & & & & & & & $\stackrel{8}{\circ}$ & \\
\hline 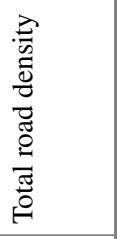 & & & & & & & & $\stackrel{8}{-}$ & 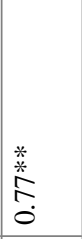 & 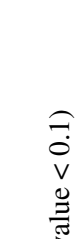 \\
\hline 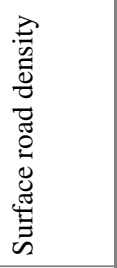 & & & & & & & $\stackrel{8}{\circ}$ & 蓄 & $\frac{*}{\stackrel{*}{*}}$ & $\begin{array}{l}= \\
0 \\
0 \\
0 \\
0 \\
0 \\
0 \\
0 \\
0\end{array}$ \\
\hline 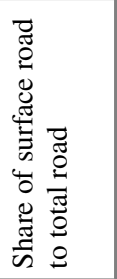 & & & & & & $\underset{-}{8}$ & 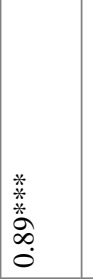 & 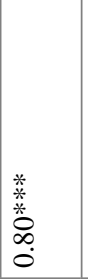 & 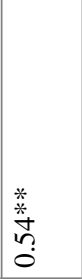 & 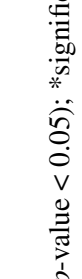 \\
\hline 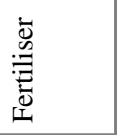 & & & & & $\stackrel{8}{8}$ & 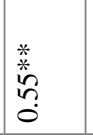 & \begin{tabular}{l}
$\frac{*}{*}$ \\
\multirow{2}{*}{$\hat{2}$} \\
$\stackrel{2}{0}$ \\
0
\end{tabular} & 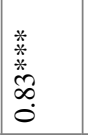 & \begin{tabular}{l} 
*.*. \\
\multirow{*}{*}{} \\
$\stackrel{0}{0}$
\end{tabular} & 己 \\
\hline 美 & & & & $\underset{8}{8}$ & \begin{tabular}{l}
$*$ \\
$*$ \\
$*$ \\
\multirow{2}{*}{} \\
$\dot{0}$ \\
\end{tabular} & 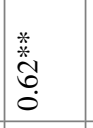 & $\begin{array}{l}* \\
* \\
* \\
* \\
\infty \\
0 \\
0 \\
\end{array}$ & $\begin{array}{l}* \\
* \\
* \\
* \\
\infty \\
0 \\
0 \\
\end{array}$ & 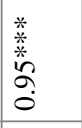 & 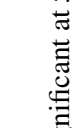 \\
\hline 훙 & & & $\stackrel{8}{\circ}$ & $\begin{array}{l}0 \\
0 \\
0\end{array}$ & 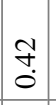 & 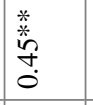 & 彝 & $\stackrel{*}{\stackrel{*}{*}} \stackrel{.}{\circ}$ & $\stackrel{0}{0}$ & $\begin{array}{l}\text { * } \\
* \\
*\end{array}$ \\
\hline 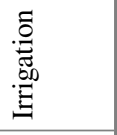 & & $\underset{-}{8}$ & \begin{tabular}{l}
$*$ \\
\multirow{*}{*}{} \\
$\stackrel{*}{0}$ \\
0 \\
0
\end{tabular} & 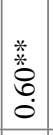 & \begin{tabular}{|c|}
$*$ \\
$\stackrel{*}{*}$ \\
$\stackrel{*}{*}$ \\
0 \\
0 \\
0
\end{tabular} & $\begin{array}{l}\stackrel{*}{*} \\
\stackrel{*}{*} \\
\stackrel{*}{0}\end{array}$ & 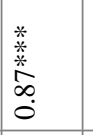 & $\begin{array}{l}* \\
* \\
* \\
\infty \\
\infty \\
0 \\
0\end{array}$ & 密 & $\begin{array}{l}v \\
\text { J } \\
\text { ש }\end{array}$ \\
\hline 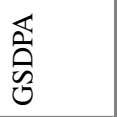 & $\stackrel{8}{\circ}$ & 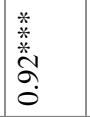 & 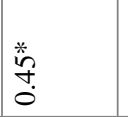 & 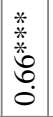 & 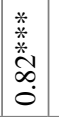 & $\begin{array}{l}* \\
\frac{*}{*} \\
\stackrel{0}{0} \\
0\end{array}$ & \begin{tabular}{l}
$*$ \\
\multirow{*}{*}{} \\
\multirow{*}{*}{} \\
$\infty$ \\
0 \\
0
\end{tabular} & $\begin{array}{l}* \\
* \\
* \\
* \\
0 \\
\infty \\
0 \\
0\end{array}$ & 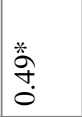 & 党 \\
\hline 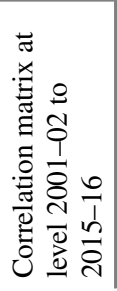 & $\mid \begin{array}{l}\nwarrow \\
0 \\
0\end{array}$ & 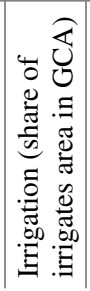 & 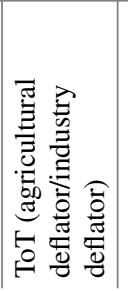 & 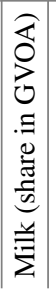 & 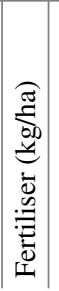 & 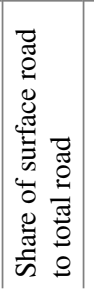 & 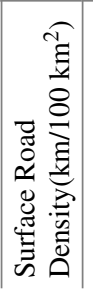 & 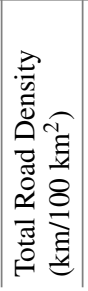 & 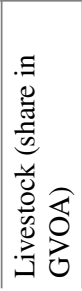 & 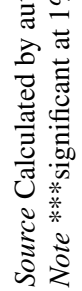 \\
\hline
\end{tabular}


Table 8.9 Description of variables

\begin{tabular}{l|l|l}
\hline IRR & $\begin{array}{l}\text { Log of share of irrigated area as a share } \\
\text { of gross cropped area }\end{array}$ & $\begin{array}{l}\text { Directorate of economics and } \\
\text { statistics (DES) }\end{array}$ \\
\hline GSDPA & $\begin{array}{l}\text { Log of gross state domestic product in } \\
\text { agriculture and allied activities }\end{array}$ & CSO \\
\hline Total road density & $\begin{array}{l}\text { Log of total road length }(\mathrm{km}) \text { per } \\
100 \mathrm{~km}^{2} \text { of the geographical area }\end{array}$ & $\begin{array}{l}\text { Ministry of roads, transports } \\
\text { and highway }\end{array}$ \\
\hline ToT & $\begin{array}{l}\text { Term of trade measured as log of } \\
\text { agricultural deflator/industry deflator }\end{array}$ & CSO \\
\hline Milk & $\begin{array}{l}\text { Log of value of output from milk as a } \\
\text { share of value of output from } \\
\text { agriculture and allied activities }\end{array}$ & CSO \\
\hline
\end{tabular}

\section{References}

Agriculture Census. (2015-16). All India report on number and area of operational holdings. Retrieved May 2019, from Agricultural Census: http://agcensus.nic.in/document/agcen1516/T1_ ac_2015_16.pdf.

Gulati, A. (2016). From plate to plough: Twenty-five years of tinkering. Indian Express, July 4, 2016. http://indianexpress.com/article/opinion/columns/india-economic-reformsindian-farmersfertiliser-subsidy-union-budget-modi-govt-organic-farming-2892089/.

Kishore, A., Sharma, B., \& Joshi, P. K. (2014). Putting agriculture on the takeoff trajectory: Nurturing the seeds of growth in Bihar, India. New Delhi, India: International Food Policy Research Institute (IFPRI) and International Water Management Institute (IWMI).

Livestock Census. (2012). 19th livestock census-2012 all India report. New Delhi: Department of Animal Husbandry, Dairying and Fisheries, Ministry of Agriculture and Farmers Welfare, Government of India.

Mishra, K. D. (1999). Flood protection that never was: Case of Mahananda Basin of North Bihar. Economic Political Weekly, 33(29).

NABARD. (2018). NABARD All India Rural Financial Inclusion Survey 2016-17 . Mumbai: NABARD

Sadoff, C., Rao, H., Blackmore, D., Wu, X., McDonnell, A., Jeuland, M., et al. (2012). Ten fundamental questions for water resources development in the Ganges: myths and realities. Water Policy, 15(S1), 147-164.

Shah, M. (2016). Eliminating poverty in Bihar: Paradoxes, bottlenecks and solutions. Economic Political Weekly, LI(6).

Vajpayee. (2018, February 24). Bihar Fasal Sahayata Yojana: Less than 3 lakh farmers applied. Retrieved from https://www.mygovernmentschemes.com/bihar-fasal-sahayata-yojana/. 
Open Access This chapter is licensed under the terms of the Creative Commons Attribution 4.0 International License (http://creativecommons.org/licenses/by/4.0/), which permits use, sharing, adaptation, distribution and reproduction in any medium or format, as long as you give appropriate credit to the original author(s) and the source, provide a link to the Creative Commons licence and indicate if changes were made.

The images or other third party material in this chapter are included in the chapter's Creative Commons licence, unless indicated otherwise in a credit line to the material. If material is not included in the chapter's Creative Commons licence and your intended use is not permitted by statutory regulation or exceeds the permitted use, you will need to obtain permission directly from the copyright holder.

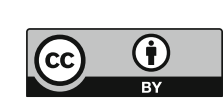

